\title{
Changes in the southeast Vatnajökull ice cap, Iceland, between $\sim 1890$ and 2010
}

\author{
H. Hannesdóttir, H. Björnsson, F. Pálsson, G. Aðalgeirsdóttir, and Sv. Guðmundsson \\ Institute of Earth Sciences, University of Iceland, 101 Reykjavík, Iceland \\ Correspondence to: H. Hannesdóttir (hrafnha@hi.is)
}

Received: 8 August 2014 - Published in The Cryosphere Discuss.: 5 September 2014

Revised: 7 February 2015 - Accepted: 11 February 2015 - Published: 19 March 2015

\begin{abstract}
Area and volume changes and the average geodetic mass balance of the non-surging outlet glaciers of the southeast Vatnajökull ice cap, Iceland, during different time periods between $\sim 1890$ and 2010 , are derived from a multi-temporal glacier inventory. A series of digital elevation models (DEMs) $(\sim 1890,1904,1936,1945,1989$, 2002, 2010) are compiled from glacial geomorphological features, historical photographs, maps, aerial images, DGPS measurements and a lidar survey. Given the mapped basal topography, we estimate volume changes since the end of the Little Ice Age (LIA) 1890. The variable volume loss of the outlets to similar climate forcing is related to their different hypsometry, basal topography, and the presence of proglacial lakes. In the post-LIA period, the glacierized area decreased by $164 \mathrm{~km}^{2}$ (or from 1014 to $851 \mathrm{~km}^{2}$ ) and the glaciers had lost $10-30 \%$ of their $\sim 1890$ area by 2010 (anywhere from 3 to $36 \mathrm{~km}^{2}$ ). The glacier surface lowered by $150-270 \mathrm{~m}$ near the terminus and the outlet glaciers collectively lost $60 \pm 8 \mathrm{~km}^{3}$ of ice, which is equivalent to $0.15 \pm 0.02 \mathrm{~mm}$ of sea-level rise. The volume loss of individual glaciers was in the range of $15-50 \%$, corresponding to a geodetic mass balance between -0.70 and $-0.32 \mathrm{mw}$.e. $\mathrm{a}^{-1}$. The annual rate of mass change during the post-LIA period was most negative in 2002-2010, on average $-1.34 \pm 0.12 \mathrm{~m}$ w.e. $\mathrm{a}^{-1}$, which is among the most negative mass balance values recorded worldwide in the early 21 st century.
\end{abstract}

\section{Introduction}

Area changes and glacier retreat rates since the Little Ice Age (LIA) maximum are known from glacierized areas worldwide (e.g. Haeberli et al., 1989; WGMS, 2008). The majority of glaciers worldwide have been losing mass during the past century (Vaughan et al., 2013), and a number of studies have estimated the volume loss and the mass balance for the post-LIA period by various methods (e.g. Rabatel et al., 2006; Bauder et al., 2007; Knoll et al., 2008; Lüthi et al., 2010; Glasser et al., 2011). Knowledge of the ice volume stored in glaciers at different times is important for past, current and future estimates of sea-level rise and water resources. More than half of the land ice contribution to sea-level rise in the 20th century comes from ice caps and glaciers outside the polar areas (Church et al., 2013). Furthermore, glacier inventories are important for analysing and assessing glacier changes at a regional scale, and they provide a basic data set for glaciological studies, for example to calibrate models simulating future glacier response to changes in climate.

Iceland is located in the northern part of the storm track in the North Atlantic Ocean, at the boundary of warm and cold ocean surface currents. The temperate maritime climate of Iceland is characterized by small seasonal variations in temperature in the lowlands; the mean temperatures are close to $0^{\circ} \mathrm{C}$ in the winter and $11^{\circ} \mathrm{C}$ during the summer months. The temperate glaciers and ice caps receive large amounts of snowfall, induced by the cyclonic westerlies crossing the North Atlantic, and have mass turnover rates in the range of 1.5-3.0 m w.e. $\mathrm{a}^{-1}$ (Björnsson et al., 2013). Simulations with a coupled positive-degree-day and ice flow model reveal that the mass balance sensitivity of southern Vatnajökull is in the range of $0.8-1.3 \mathrm{~m}$ w.e. $\mathrm{a}^{-1}{ }^{\circ} \mathrm{C}^{-1}$ (Aðalgeirsdóttir et al., 2006), which is among the highest in the world (De Woul and Hock, 2005). The results of spatially distributed coupled models of ice dynamics and hydrology indicate that these glaciers are the most sensitive to future warming of 


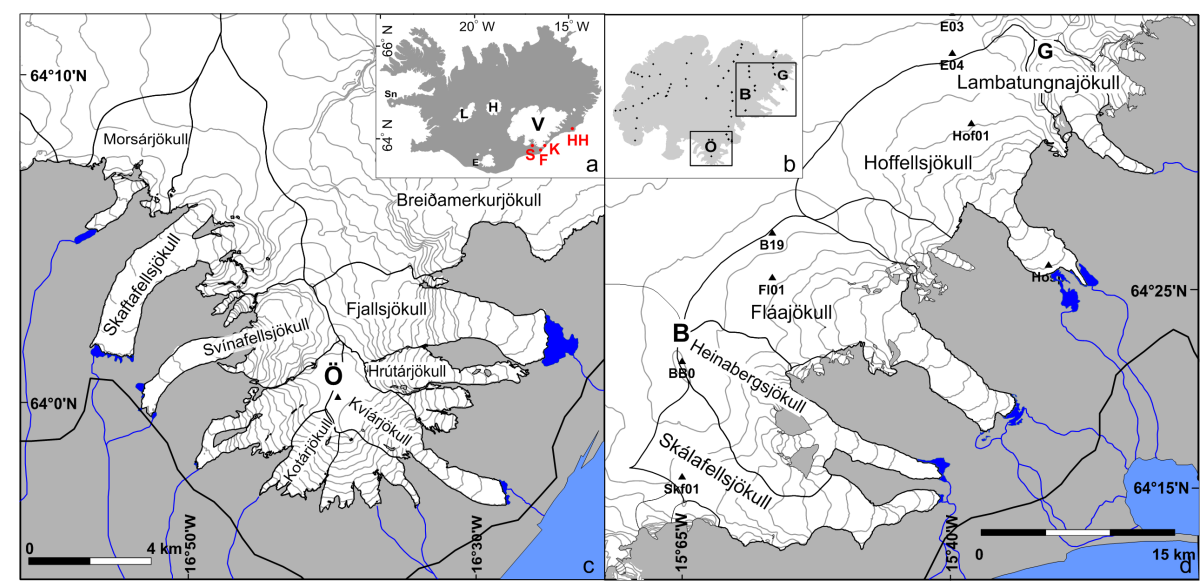

Figure 1. (a) Iceland and Vatnajökull (V) and other ice caps and glaciers mentioned in the text, Hofsjökull (H), Langjökull (L), Eyjafjallajökull (E), and Snæfellsjökull (Sn). Weather stations in Skaftafell (S), Fagurhólsmýri (F), Kvísker (K) and Hólar in Hornafjörður (HH). (b) Vatnajökull and mass balance stakes (black dots). The rectangles show the outline of figures (c) the outlet glaciers descending from Öræfajökull ice cap (Ö) and Morsárjökull, and (d) the outlet glaciers east of Breiðamerkurjökull, descending from the Breiðabunga dome (B), and Goðahnúkar (G). The surface topography is from the 2010 lidar DEMs, with 100 m contour lines, and ice divides are delineated in black. The location of mass balance measurements is indicated with triangles. Note the different scale of the two figures. Proglacial lakes and rivers are shown in blue and highway 1 in black.

all outlets of Vatnajökull (Flowers et al., 2005). Apart from Greenland, the highest rate of glacial meltwater input to the North Atlantic Ocean comes from the Icelandic glaciers, which have contributed $\sim 0.03 \mathrm{~mm} \mathrm{a}^{-1}$ on average to sealevel rise since the mid-1990s (Björnsson et al., 2013). A few quantitative estimates of volume and mass balance changes for the entire post-LIA period are available for Icelandic glaciers (Flowers et al., 2007; Aðalgeirsdóttir et al., 2011; Pálsson et al., 2012; Guðmundsson, 2014).

To estimate the area and volume loss and the geodetic mass balance of the outlets of southeast Vatnajökull since $\sim 1890$, glacier outlines were digitized from various sources, and digital elevation models (DEMs) created from contour lines of topographic maps, DGPS measurements and various airborne surveys. The snowline elevation at the end of summer, a proxy for the equilibrium line altitude (ELA), was estimated from a series of recent MODIS images. Finally, the different response of the glaciers to similar climate forcing during the post-LIA time period is analysed.

\section{Study area and previous work}

The studied outlet glaciers of southeast Vatnajökull (Fig. 1) are located in the warmest and wettest area of Iceland and descend down to the lowlands. The glaciers are nonsurging, less than $100 \mathrm{~km}$ apart and most of them reach down to $20-100 \mathrm{~m}$ a.s.l. (Fig. 1). The glaciers vary in size from $10-200 \mathrm{~km}^{2}$, their average thickness range is $80-330 \mathrm{~m}$ (Table 1). Öræfajökull (2110 ma.s.l.), the highest peak in Iceland, feeds the steeper outlet glaciers of this study. The outlet glaciers east of Breiðamerkurjökull, which will hereafter be referred to as the eastern outlet glaciers, descend down from ice divides at around $1500 \mathrm{~m}$ a.s.l.

The basal topography of the outlets is known from radio echo sounding measurements (see Björnsson (2009) and Magnússon et al. (2012) for details). The glaciers terminate in glacially eroded valleys and have carved into soft glacial and glacio-fluvial sediments. The glaciers are particularly vulnerable to warming climate conditions, since their beds lie $100-300 \mathrm{~m}$ at their deepest below the elevation of the current terminus (Björnsson and Pálsson, 2008; Magnússon et al., 2012), and terminate in proglacial lakes that enhance their retreat. Assuming current climate conditions or warming, the lakes will continue to grow and new ones form in the troughs as the glaciers retreat, and will cause enhanced ablation, at least until they retreat out of the lakes.

The surface geometry of the outlet glaciers at the LIA maximum has been reconstructed from glacial geomorphological features and historical data (Hannesdóttir et al., 2014). The outlets were at their terminal LIA moraines around $\sim 1890$, which marked the termination of the LIA in Iceland (Thórarinsson, 1943; Hannesdóttir et al., 2014).

Mass balance measurements have been carried out on Vatnajökull since 1993, and the ice cap has on average lost approximately $1 \mathrm{~m}$ w.e. $\mathrm{a}^{-1}$ in the time period $1993-$ 2012 (Björnsson et al., 2013). The majority of the ablation stakes are located on the northern and western outlet glaciers (Fig. 1), but a number of stakes are located on Breiðamerkurjökull and a few on the eastern outlets (Björnsson and Pálsson, 2008; Aðalgeirsdóttir et al., 2011). On these glaciers, the annual mass balance has been measured as $1-4 \mathrm{mw}$.e. $\mathrm{a}^{-1}$ in the accumulation area in the time period 1996-2010. Losses of up to $9 \mathrm{mw}$.e. $\mathrm{a}^{-1}$ 
Table 1. Characteristics of the southeast outlet glaciers in 2010. Some glaciers have gently sloping accumulation and ablation areas, which are connected by ice falls, thus the mean slope is not representative for the entire profile. The ELA is presented as the averages of the years 2007-2011 with the standard deviation. Average ice thickness, the AAR and terminus elevation are presented in $\sim 1890$ and 2010 .

\begin{tabular}{|c|c|c|c|c|c|c|c|c|c|c|c|}
\hline Glacier & $\begin{array}{r}\text { Slope } \\
\left({ }^{\circ}\right)\end{array}$ & $\begin{array}{c}\text { Ice divide } \\
\text { (m a.s.1.) }\end{array}$ & $\begin{array}{r}\text { Area } \\
\left(\mathrm{km}^{2}\right)\end{array}$ & $\begin{array}{r}\text { Volume } \\
\left(\mathrm{km}^{3}\right)\end{array}$ & $\begin{array}{l}\text { Thickness } \\
\text { (m) }\end{array}$ & AAR & $\begin{array}{r}\text { ELA } \\
\text { (m a.s.l.) }\end{array}$ & $\begin{array}{r}\text { Length } \\
(\mathrm{km})\end{array}$ & $\begin{array}{l}\text { Term. elev. } \\
\text { (m a.s.l.) }\end{array}$ & $\begin{array}{l}\text { Retreat } \\
(\mathrm{km})\end{array}$ & Hypsom. \\
\hline Morsárj. & 6.3 & 1350 & 28.9 & 6.0 & $215 / 208$ & $0.75 / 0.64$ & $1065 \pm 65$ & 10.8 & $150 / 170$ & 1.8 & B \\
\hline Skaftafellsj. & 3.8 & 1880 & 84.1 & 20.3 & $254 / 241$ & $0.63 / 0.66$ & $1080 \pm 80$ & 19.3 & $80 / 95$ & 2.5 & B \\
\hline Svínafellsj. & 9.0 & 2030 & 33.2 & 3.6 & $132 / 108$ & $0.63 / 0.66$ & $1060 \pm 60$ & 12.0 & $90 / 100$ & 0.8 & $\mathrm{E}$ \\
\hline Kotárj. & 13.3 & 1820 & 11.5 & 1.7 & $152 / 148$ & $0.81 / 0.71$ & $1065 \pm 65$ & 6.2 & $220 / 400$ & 1.3 & $\mathrm{~B} / \mathrm{D}$ \\
\hline Kvíárj. & 6.0 & 2010 & 23.2 & 4.1 & $187 / 177$ & $0.62 / 0.64$ & $1070 \pm 60$ & 14.1 & $30 / 30$ & 1.5 & $\mathrm{E}$ \\
\hline Hrútárj. & 12.4 & 1980 & 12.2 & 0.9 & $111 / 74$ & $0.64 / 0.58$ & $895 \pm 15$ & 8.6 & $50 / 60$ & 2.0 & $\mathrm{~A} / \mathrm{C}$ \\
\hline Fjallsj. & 7.9 & 2030 & 44.6 & 7.0 & $185 / 157$ & $0.55 / 0.60$ & $915 \pm 45$ & 12.9 & $20 / 30$ & 2.2 & $\mathrm{E} / \mathrm{C}$ \\
\hline Skálafellsj. & 3.1 & 1490 & 100.6 & 33.3 & $332 / 331$ & $0.73 / 0.68$ & $965 \pm 55$ & 24.4 & $40 / 50$ & 2.0 & B \\
\hline Heinabergsj. & 3.7 & 1490 & 99.7 & 26.7 & $308 / 268$ & $0.64 / 0.61$ & $1045 \pm 55$ & 22.7 & $60 / 70$ & 2.9 & $\mathrm{~B} / \mathrm{C}$ \\
\hline Fláaj. & 3.1 & 1480 & 169.8 & 53.9 & $313 / 317$ & $0.76 / 0.59$ & $1090 \pm 30$ & 25.1 & $40 / 70$ & 2.7 & $\mathrm{~B}$ \\
\hline Hoffellsj. & 3.4 & 1470 & 206.0 & 54.3 & $303 / 264$ & $0.79 / 0.63$ & $1085 \pm 35$ & 23.6 & $30 / 50$ & $4.0^{*}$ & $\mathrm{~B} / \mathrm{D}$ \\
\hline Lambatungnaj. & 5.0 & 1480 & 36.3 & 3.6 & $135 / 99$ & $0.61 / 0.43$ & $1160 \pm 50$ & 19.3 & $180 / 250$ & 2.7 & $\mathrm{D}$ \\
\hline
\end{tabular}

* The retreat applies to the western arm of Hoffellsjökull (named Svínafellsjökull).

have been observed during summer on Breiðamerkurjökull and Hoffellsjökull, and even negative winter balances at the terminus (Björnsson and Pálsson, 2008). The mass balance at the plateau of the Öræfajökull ice cap (1750-1900 ma.s.l.) was 6-8 m w.e. $\mathrm{a}^{-1}$ in $1993-1998$ (Guðmundsson, 2000). Based on satellite imagery, in situ mass balance measurements and model simulations, the average ELA of southeast Vatnajökull has been estimated to be around 1100-1200 m (Björnsson, 1979; Aðalgeirsdóttir et al., 2005, 2006; Björnsson and Pálsson, 2008; Aðalgeirsdóttir et al., 2011). Interannual variability of approximately $200-300 \mathrm{~m}$ of the ELA was measured in the time period 1992-2007 (Björnsson and Pálsson, 2008).

Regular monitoring of annual frontal variations of the outlets of southeast Vatnajökull started in 1932 by Jón Eypórsson and were later carried out by volunteers of the Icelandic Glaciological Society (Eypórsson, 1963; Sigurðsson, 2013, http://spordakost.jorfi.is). The history of retreat and volume changes of Hoffellsjökull since the end of the LIA has been derived from numerous archives (Aðalgeirsdóttir et al., 2011; Björnsson and Pálsson, 2004). Downwasting and volume loss of Kotárjökull (Fig. 1) in $\sim 1890-2010$ has been quantified by repeat photography and mapping of LIA glacial geomorphological features (Guðmundsson et al., 2012). The records of these two glaciers are integrated in our data base for comparison with the other outlets of southeast Vatnajökull.

\section{Data}

\subsection{Meteorological records}

Long temperature and precipitation records are available from two lowland weather stations (Fig. 1) south of Vatnajökull; at Fagurhólsmýri (16 ma.s.l., $8 \mathrm{~km}$ south of
Öræfajökull) and Hólar in Hornafjörður (16 m a.s.l., 15 km south of Hoffellsjökull). The temperature record at Hólar is available for the period 1884-1890 and since 1921, whereas the precipitation measurements started in 1931 (Fig. 2). Temperature measurements started in 1898 at Fagurhólsmýri, and the precipitation record goes back to 1921 (Fig. 2). The temperature and precipitation records were extended back to the end of the 19th century, following the methodology of Aðalgeirsdóttir et al. (2011). The mean summer (June-August) temperature during the two warmest ten year periods of the measurement series at Hólar (19301940 and $2000-2010$ ) was $10.4^{\circ} \mathrm{C}$. For comparison, the mean summer temperature for the time period 1884-1890 (the only years of measurements in the 19th century) was $8.5^{\circ} \mathrm{C}$. Winter precipitation ranges between 800 and $1400 \mathrm{~mm}$, and no long term trend is observed since the start of measurements at the two stations. Precipitation has been measured at Kvísker (east of Öræfajökull) since 1963, and at Skaftafell (west of Öræfajökull) since 1964. The records from Kvísker show more than two times higher winter precipitation than in Skaftafell (Fig. 2), but the annual precipitation is three times higher (not shown). This seasonal difference could be related to precipitation undercatch of the rain gauges especially during winter, which is generally more pronounced for snow than rain (e.g. Sigurðsson, 1990).

\subsection{Glacier geometry}

The areal extent and the surface topography of the outlet glaciers at different times during the period $\sim 1890-2010$, was derived from various data sets (Table 2) that are detailed in the following sub-chapters. The glacier margin was digitized from maps and aerial images at various times for different glaciers. 

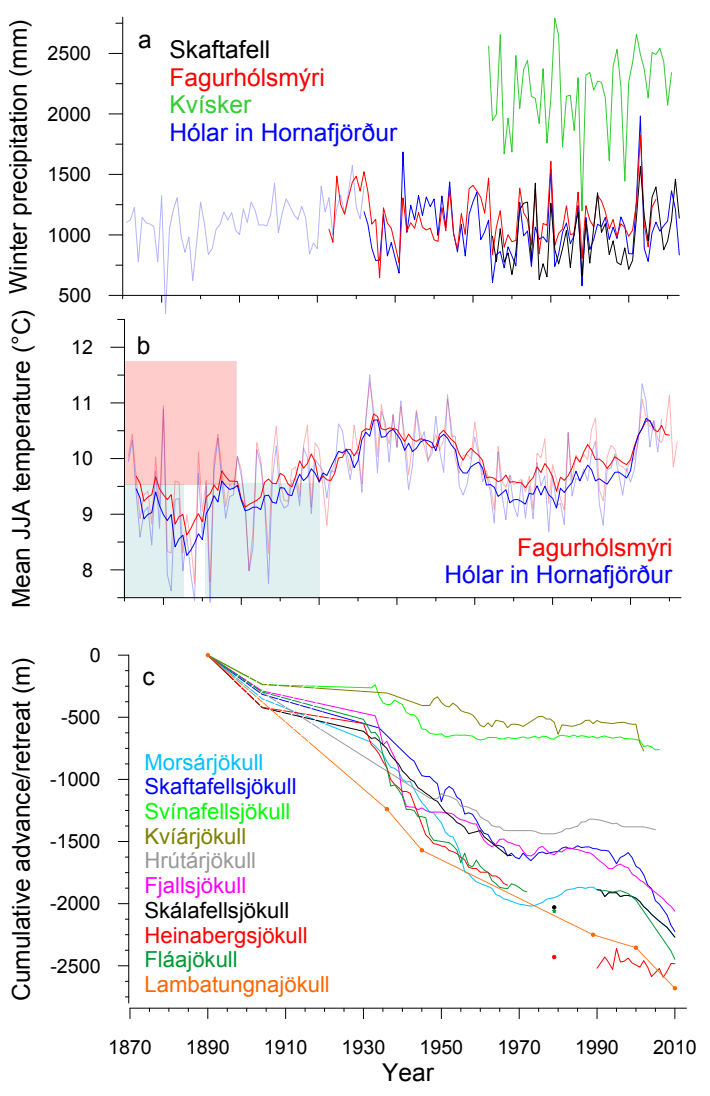

Figure 2. (a) Winter precipitation (October-April in $\mathrm{mm}$ ) at Skaftafell (black), Fagurhólsmýri (red), Kvísker (green) and Hólar in Hornafjörður (blue), see Fig. 1a for the location of stations. Reconstructed precipitation indicated with a light blue line (from Aðalgeirsdóttir et al., 2011). (b) Mean summer (JJA) temperature at Fagurhólsmýri (red) and Höfn in Hornafjörður (blue) and 5 years running average. Light blue and light red boxes indicate the time period of reconstructed temperature (from Aðalgeirsdóttir et al., 2011). (c) Cumulative frontal variations of the southeast outlet glaciers relative to the $\sim 1890$ terminus position determined from the terminal LIA moraines (Hannesdóttir et al., 2014). The retreat until 1932, when measurements of volunteers of the Icelandic Glaciological Society started, is indicated by broken lines; the position in 1904 is known from the maps of the Danish General Staff; note that a linear recession is not expected in $\sim 1890-1904$ or 1904-1932. Annual measurements are shown with a solid line (http://spordakost.jorfi.is). Skálafellsjökull, Heinabergsjökull and Fláajökull were not measured in the 1970s and 1980s, but their terminus position in 1979 is determined from aerial images of the National Land Survey of Iceland (indicated by dots). The terminus of Lambatungnajökull (orange line) has not been measured, but its recession is retrieved from maps, aerial photographs and satellite images.

\subsubsection{Lidar DEM}

The most accurate DEMs of southeast Vatnajökull have been produced with airborne lidar technology in late AugustSeptember 2010 and 2011 (Icelandic Meteorological Office and Institute of Earth Sciences, 2013). The high-resolution DEMs are $5 \mathrm{~m} \times 5 \mathrm{~m}$ in pixel size with a $<0.5 \mathrm{~m}$ vertical and horizontal accuracy (Jóhannesson et al., 2013). The lidar DEMs provide a reference topography, used to construct other glacier surface DEMs, for example in areas where corrections of contour lines from old paper maps were necessary.

\subsubsection{The LIA glacier surface topography}

The LIA maximum $\sim 1890$ surface topography (the timing based on historical documents) of the outlet glaciers of this study has previously been reconstructed from glacial geomorphological features (including lateral and terminal moraines, trimlines and glacier erratics), historical photographs, and aerial images, using the lidar DEM as baseline topography (Hannesdóttir et al., 2014). The vertical accuracy of the $\sim 1890$ DEM is estimated to be around $\pm 15-$ $20 \mathrm{~m}$ (see Hannesdóttir et al. (2014) for details).

\subsubsection{Aerial images, maps and glacier surface data}

The oldest reliable maps of the outlet glaciers are from the Danish General Staff $(1: 50000)$, based on trigonometrical geodetic surveys conducted in the summers of 1902-1904 (Danish General Staff, 1904). Considerable distortion was observed in the horizontal positioning, related to errors in the survey network established by the Danish Geodetic Institute (Böđvarsson, 1996; Pálsson et al., 2012). Fewer errors are found in the vertical component, revealed by comparison of the elevation of trigonometric points on mountain peaks and other definite landmarks between the lidar DEM and the 1904 maps (see also Guðmundsson et al., 2012). The 1904 maps do not cover all the outlet's glaciers up to their ice divides. The Öræfajökull outlets have a complete coverage except Skaftafellsjökull and Morsárjökull, leaving $28 \%$ of the total area of the Öræfajökull outlets unmapped. Three of the eastern outlets (Skálafellsjökull, Heinabergsjökull and Fláajökull) were mapped in 1904, but most of the accumulation area was not surveyed, resulting in $67 \%$ of their area being unmapped. Lambatungnajökull was not surveyed in the early 20th century, but a manuscript map exists from 1938, based on a trigonometric geodetic survey and oblique photographs of the Danish General Staff (archives of the National Land Survey of Iceland). Only a small part of the terminus of Hoffellsjökull was surveyed in 1904, but a map from 1936 covers the whole glacier.

The AMS (Army Map Service) 1:50000 maps with $20 \mathrm{~m}$ contour lines (Army Map Service, 1950-1951) cover all the outlet glaciers up to the ice divides. They are based on aerial photographs taken in August-September 1945 and 1946. The geometry in the upper parts of the glaciers, above $\sim 1100 \mathrm{~m}$ elevation, was based on the surveys of the Danish General Staff from the 1930s and 1940s, where contour lines are only estimates, indicating shape, not accurate elevation (see 
also Pálsson et al., 2012). The unpublished DMA maps from 1989 (Defense Mapping Agency, 1997) include only the eastern outlet glaciers. These maps were similarly derived by standard aerial photographic methods, based on images taken in August-September 1989, with a scale of $1: 50000$ and $20 \mathrm{~m}$ contour lines.

A Landsat satellite image from 1999 and aerial photographs from 1945, 1946, 1960, 1982 and 1989 (http: //www.lmi.is/loftmyndasafn) and from 2002 (http://www. loftmyndir.is) were used to delineate the glacier margin (Table 2). The glacier margins of the Öræfajökull outlet glaciers were digitized from the high-resolution aerial images of Loftmyndir ehf from 2002 (with a horizontal resolution of $2.5 \mathrm{~m}$ ), whereas the glacier margins of the eastern outlets were digitized from a Landsat satellite image from 28 July 1999 (with a horizontal resolution of $\pm 30 \mathrm{~m}$, http://landsat.usgs.gov).

The aerial images were used to estimate surface elevation changes in the accumulation area from the appearance of nunataks (isolated rock outcrops within the glaciers), as they grow due to lowering of the glacier surface. A $20 \mathrm{~m} \times 20 \mathrm{~m}$ DEM from the company Loftmyndir ehf., based on late summer aerial images from 2002, covers parts of Öræfajökull's outlet glaciers with a vertical accuracy of $<5 \mathrm{~m}$, excluding most of the accumulation areas. The DGPS surface elevation measurements on southeast Vatnajökull (with a vertical accuracy of $1-2 \mathrm{~m}$ ), carried out during repeated mass balance surveys, and radio echo sounding profiling in spring (during the time period 2000-2003), are used for DEM construction.

\subsubsection{Basal topography}

The basal topography has been derived from radio echo sounding measurements, carried out in the last two decades (Björnsson and Pálsson, 2004, 2008; Björnsson, 2009; Magnússon et al., 2007, 2012, and the data base of the Glaciology Group of the Institute of Earth Sciences, University of Iceland=GGIES). We calculate the total ice volume from the bed DEMs and the ice volume changes as a fraction of the total volume. The accuracy of the measurements of the subglacial topography is $\pm 5-20 \mathrm{~m}$, depending on location.

\section{Methods}

\subsection{Glacier surface DEMs}

The glacier surface DEMs were used to determine changes in elevation and volume, and to infer mass changes (e.g. Reinhardt and Rentsch, 1986; Kääb and Funk, 1999). Comparison of 2002 DEMs retrieved from the aerial images of Loftmyndir ehf., SPOT5 HRS images from autumn 2008 (Korona et al., 2009), and the 2010 lidar, revealed that the surface geometry in the upper accumulation area has undergone negligible changes during the first decade of the 21 st century, at a time of rapid changes in the ablation area (see also Björnsson and Pálsson, 2008). Minor changes in the surface geometry in the upper accumulation area of a western outlet of Vatnajökull in 1998-2010 have similarly been observed (Auriac et al., 2014). When constructing the DEMs of 1938, 1945, 1989 and 2002, it was therefore assumed that the glacier surface geometry in the upper reaches of the accumulation area did not change, but the estimated vertical displacement was superimposed on the lidar DEM. The DEMs were obtained by constructing new contour lines from each contour line of the lidar DEM; the new contour having the elevation of the lidar plus an elevation shift. The intersection point of the new contour with the valley wall is found by moving the old point up or down the wall by a vertical elevation change along a line drawn between the old intersection points on the opposite sides of the valley. We consider the average vertical bias of each DEM to be smaller than the estimated point accuracy, which is provided in Table 5.

The various DEMs were merged into a common data set, coregistered and georeferenced, and the lidar data providing the reference DEM. Regular $50 \mathrm{~m} \times 50 \mathrm{~m}$ DEMs were created by digitizing the contour lines of the paper maps $(1904,1938,1945,1989)$ and interpolated using the point Kriging method (e.g. Wise, 2000). The appearance of nunataks was used to determine ice surface elevation changes in the accumulation area of the southeast outlets, as has been done to estimate downwasting elsewhere (Paul et al., 2007; Rivera et al., 2007; Berthier et al., 2009; Pelto, 2010). The aerial images were laid on top of and georeferenced with a shaded relief lidar image and the outline of the nunataks digitized. Most of the nunataks have steep slopes and the variable snow cover around them is incorporated in the error assessment. This approach provided new estimates for surface elevation changes in the upper accumulation area of the glaciers. The surface change data was extrapolated headward as a linear variation between the elevation change data points - retrieved from the trigonometric survey points (1904 map) and the nunataks.

Due to lack of accurate contour lines in the highest part of the accumulation areas, we assumed that ice divides were fixed in time, which may introduce an error in the area estimate. The ice divides were determined from the lidar DEM and the data base of the GGIES. Even though there have been surges in the larger outlets of Vatnajökull (Björnsson et al., 2003), they have not affected the ice divides of the studied southeast outlet glaciers during the study period. Uplift rates around Vatnajökull in the last 20 years have been on the order of $10-30 \mathrm{~mm} \mathrm{a}^{-1}$, highest around the edge of the ice cap (Árnadóttir et al., 2009; Auriac et al., 2013). We do not however, account for this change of the bed elevation in the glacier surface DEMs, as it is smaller than the vertical error estimate. 
Table 2. Overview of the data sets used to delineate the glacier margin, create DEMs, MODIS images to extract the late summer snowline (proxy for the ELA).

\begin{tabular}{|c|c|c|}
\hline Data set & Time period/details & Reference/photographer \\
\hline Aerial images & $2002-2004$ & Loftmyndir ehf. (http://www.loftmyndir.is) \\
\hline Oblique photographs & $2000-2012$ & Helgi Björnsson, Snævarr Guðmundsson, Vỉðir Reynisson \\
\hline Aerial photographs & $1945,1960,1982,1989$ & NLS (http://www.lmi.is/loftmyndasafn) \\
\hline SPOT5 & 2005 & SPOT5 (Spot Image) \\
\hline Landsat & 2000 & http://landsat.usgs.gov \\
\hline MODIS & $2007-2011$ & http://rapidfire.sci.gsfc.nasa.gov/gallery/ \\
\hline Lidar & $2010-2011$ & IMO and IES \\
\hline Danish General Staff maps & 1904 & Danish General Staff, 1904 \\
\hline $87 \mathrm{SA}$ & Öræfajókull & Öræfajókull and the upper part of accumulation area of Skaftafellsj. and Svínafellsj. \\
\hline $87 \mathrm{SV}$ & Öræfajókull & The lower ablation area of Morsárj., Skaftafellsj. and Svínafellsj. \\
\hline $87 \mathrm{NV}$ & Öræfajókull & Morsárjókull and part of the upper accumulation area of Skaftafellsjökull \\
\hline $96 \mathrm{NA}$ & Heinaberg & Part of ablation area of Skálafellsj. and Heinabergsj., Fláaj., snout of Hoffellsj. \\
\hline $97 \mathrm{NA}$ & Kálfafellsstaður & Sultartungnajökull, outlet of Skálafellsjökull \\
\hline $97 \mathrm{NV}$ & Kálfafellsstaður & Part of the western rim of Sálafellsjökull \\
\hline AMS maps (Series C762) & 1945 & Army Map Service, 1950-1951 \\
\hline 6018-I & Kvísker & \\
\hline 6018-IV & Svínafell & \\
\hline 6019-I & Veðurárdalsfjöll & \\
\hline 6019-II & Breiðamerkurjökull & \\
\hline 6019-III & Öræfajökull & \\
\hline 6019-IV & Esjufjöll & \\
\hline 6020-I & Vatnajökull I & \\
\hline 6020-II & Vatnajökull II & \\
\hline 6020-III & Vatnajökull III & \\
\hline 6119-IV & Kálfafellsstaður & \\
\hline 6120-I & Lambatungnajökull & \\
\hline 6120-II & Hoffell & \\
\hline 6120-III & Hoffellsjökull syðri & \\
\hline DMA maps (Series C761) & 1989 & Defense Mapping Agency, 1997 \\
\hline 2213-I & Hornafjörður & \\
\hline 2213-III & Hestgerðislón & \\
\hline 2213-IV & Heinabergsjökull & \\
\hline 2214-II & Kollumúli & \\
\hline 2214-III & Eyjabakkajökull & \\
\hline DGPS surveys & $2000-2005$ & Data base of GGIES \\
\hline Satellite image & Date & Details \\
\hline MODIS & 24 August 2007 & Iceland.2007236.terra.250m \\
\hline MODIS & 27 August 2007 & Iceland.2007239.terra. $250 \mathrm{~m}$ \\
\hline MODIS & 2 September 2007 & Iceland.2007245.terra. $250 \mathrm{~m}$ \\
\hline MODIS & 11 September 2007 & Iceland.2007254.terra. $250 \mathrm{~m}$ \\
\hline MODIS & 26 September 2007 & Iceland.2007269.terra. $250 \mathrm{~m}$ \\
\hline MODIS & 22 August 2009 & Iceland.2008234.terra. $250 \mathrm{~m}$ \\
\hline MODIS & 3 September 2008 & Iceland.2008247.terra. $250 \mathrm{~m}$ \\
\hline MODIS & 26 September 2008 & Iceland.2008269.terra. $250 \mathrm{~m}$ \\
\hline MODIS & 22 August 2009 & Iceland.2009234.terra. $250 \mathrm{~m}$ \\
\hline MODIS & 29 August 2009 & Iceland.2009241.terra. $250 \mathrm{~m}$ \\
\hline MODIS & 4 September 2009 & Iceland.2009247.terra. $250 \mathrm{~m}$ \\
\hline MODIS & 12 September 2009 & Iceland.2009255.terra. $250 \mathrm{~m}$ \\
\hline MODIS & 21 August 2010 & Iceland.2010233.terra. $250 \mathrm{~m}$ \\
\hline MODIS & 28 August 2010 & Iceland.2010240.terra. $250 \mathrm{~m}$ \\
\hline MODIS & 25 August 2011 & Iceland.2011237.terra. $250 \mathrm{~m}$ \\
\hline MODIS & 13 September 2011 & Iceland.2011256.terra. $250 \mathrm{~m}$ \\
\hline
\end{tabular}



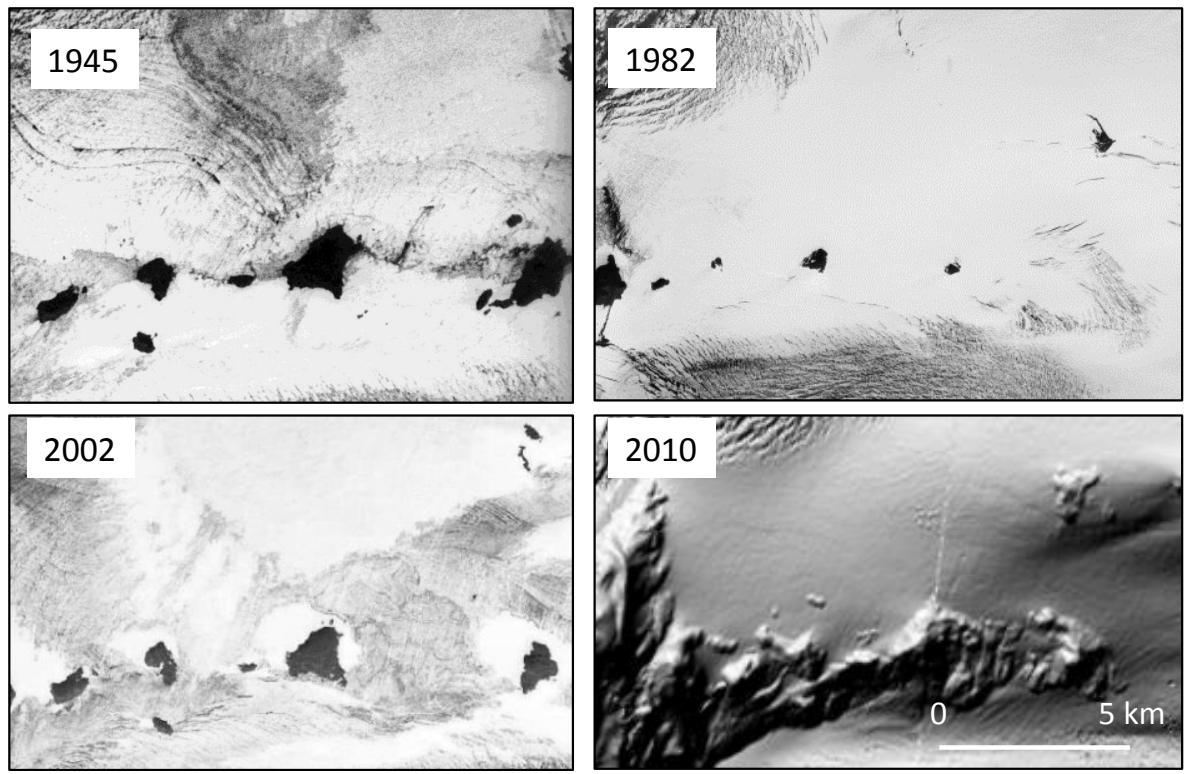

Figure 3. Small nunataks at an elevation of 950-1050 m, east of the mountain "Skerið milli skarða", which divides the main branch of Skaftafellsjökull (see Fig. 5), at different times. Aerial photograph of the National Land Survey of Iceland 1945 and 1982 , aerial image of Loftmyndir ehf. from 2002, lidar shaded relief map from 2010. Only the largest mid-nunatak is visible on the 1904 map (not shown).

\subsubsection{DEMs of 1904 and 1938}

The glacier margin delineated on the 1904 maps coincides with the LIA $\sim 1890$ lateral moraines around an elevation of $400-500 \mathrm{~m}$, thus surface lowering is assumed to only have taken place below that elevation during the relatively cold period 1890-1904 (see Hannesdóttir et al. (2014) for details of the method). A 1904 DEM of the terminus below 400-500 $\mathrm{m}$ was reconstructed and subtracted from the $\sim 1890$ DEM (Hannesdóttir et al., 2014), to calculate volume changes for the period $\sim 1890-1904$. Contour lines on the 1904 map indicate only the glacier surface geometry, not accurate elevation. The elevation of the trigonometric survey points on the glacier surface on the 1904 maps, serve as a base for generating the DEM, with an estimated vertical accuracy of $10-15 \mathrm{~m}$. The contour lines of the manuscript map of 1938 of Lambatungnajökull were digitized, and their shape adjusted to resemble the more accurate contour lines of the AMS 1945 map.

\subsubsection{DEMs of 1945}

Due to the errors in the old trigonometric network for Iceland, parts of the 1945 maps are distorted horizontally. Sections of the scanned maps were thus georeferenced individually, by fitting each map segment to the surrounding valley walls, using the lidar as reference topography. To estimate glacier surface elevation changes in the accumulation area between 1945 and 2010, we compared the size of nunataks on the original aerial images and the lidar shaded relief images (an example shown in Fig. 3). No difference in surface elevation was observed above 1300 $1400 \mathrm{~m}$, wherefrom the lidar DEM was added to create a continuous 1945 DEM. The glacier margin was revised by analysing the original aerial images, for example in areas where shadows had incorrectly been interpreted as rock outcrops or snow-covered gullies and valley walls as glacial ice. For the 1945 DEM, a conservative vertical error estimate of 5-10 $\mathrm{m}$ was made.

\subsubsection{DEMs of 1989}

DEMs from the contour lines of the DMA unpublished maps of the eastern outlets have previously been created by the GGIES. Some adjustments were made to the glacier surface geometry in the upper accumulation area, based on comparison of the size of the nunataks on the original aerial images and the shaded relief image of the lidar DEM. The glacier outline was also revised by digitizing the glacier margin from the original aerial images in areas of misinterpretation, as on the 1945 images. A conservative vertical error of $5 \mathrm{~m}$ for the 1989 DEM was estimated, based on previous studies of Icelandic glaciers using the DMA maps (Guðmundsson et al., 2011; Pálsson et al., 2012).

\subsubsection{DEMs of 2002}

Negligible surface elevation changes above 1300-1400m were observed between the aerial images of the company Loftmyndir ehf. from 2002 and the shaded relief of the 2010 lidar DEM; thus, the high-resolution lidar DEM was spliced with the 2002 DEM (above that elevation) to create 
a complete 2002 DEM. Comparison of the altitude in ice free areas bordering the glaciers, between the lidar and the Loftmyndir ehf. DEMs, revealed a vertical bias of 2-5 m. The surface elevation in the accumulation area was verified by spring DGPS measurements from radio echo sounding survey transects of the same year.

A $\sim 2002$ DEM of the eastern outlet glaciers was constructed from a series of DGPS measurements from survey transects of radio echo sounding measurements in the time period 2000-2003. The spring DGPS elevation measurements in the accumulation area were corrected by subtracting the difference between spring and autumn elevation from the measured surface, to create an autumn DEM. Seasonal changes in glacier surface elevation amount to $5 \mathrm{~m}$ on average in the accumulation area, observed at mass balance stakes on southeast Vatnajökull every autumn and spring during the period 1996-2010. The vertical error estimate for the 2002 DEM was estimated to be approximately $1-2 \mathrm{~m}$.

\subsection{Glacier hypsometry}

The hypsometry (area distribution with altitude) of individual glaciers plays an important role for their response to climate change through its link with mass-balance gradient (e.g. Ahlmann and Thorarinsson, 1943; Furbish and Andrews, 1984; Oerlemans et al., 1998). The hypsometry is determined from the basal topography, ice thickness, ice volume distribution and glacier dynamics (e.g. Jiskoot et al., 2001; Marshall, 2008; Jiskoot et al., 2009).

Five main hypsometric classes are presented in De Angelis (2014), first proposed by Osmaston (1975) and also presented in Furbish and Andrews (1984):

a. glaciers with a uniform hypsometry, i.e. area is constant with elevation;

b. glaciers where the bulk of the area lies above the ELA;

c. glaciers where the bulk of the area lies below the ELA;

d. glaciers where the bulk of the area lies at the ELA;

e. glaciers with bimodal hypsometric curves, where the ELA lies approximately between two peaks.

The hypsometric curves of the outlets of southeast Vatnajökull were generated from the lidar DEM and $\sim 1890$ DEM by creating histograms of the elevation data with $50 \mathrm{~m}$ elevation intervals.

\subsection{The snowline altitude derived from MODIS imagery and the lidar DEMs}

The elevation of the snowline at the end of the ablation season provides an estimate for the ELA on temperate glaciers (e.g. Östrem, 1975; Cuffey and Paterson, 2010). Satellite data have been used to estimate the ELA by this approximation in remote regions and where mass balance is not measured (e.g. Barcaza et al., 2009; Jiskoot et al., 2009; Mathieu et al., 2009; Mernild et al., 2013; Rabatel et al., 2013; Shea et al., 2013). Since limited mass balance measurements exist for the outlet glaciers of this study (Fig. 1, except Breiðamerkurjökull and Hoffellsjökull), the snowline retrieved from autumn MODIS images (dated 22 August to 26 September 2007-2011) is a useful proxy for the present day ELA. The MODIS images are available on a daily basis, and only cloud-free images were selected to digitize the snowline (Table 2). The snowline was manually digitized and projected on to the lidar DEMs to obtain its elevation. The average snowline elevation and standard deviation was calculated for the glaciers from each image (Table 1). The accumulation area ratio (AAR) of the outlet glaciers was estimated from the average snowline elevation from all years and the glacier margin in 2010. The estimated MODIS snowline of 2007-2011 is at similar elevation as the ELA derived from mass balance measurements on Hoffellsjökull and Breiðamerkurjökull (Aðalgeirsdóttir et al., 2011; Guðmundsson, 2014).

\subsection{Volume calculations and average geodetic mass balance}

Ice volume changes for the different time periods since the end of the LIA until 2010 were obtained by subtracting the DEMs from each other. Given the bed DEMs, the total volume loss is calculated. The volume change is the average elevation change $(\Delta h)$ between two years, multiplied by the area of the glacier,

$\Delta V=\Delta h \times A$.

The ice volume change is converted to average annual mass balance, $b_{n}$, expressed in $\mathrm{m}$ of water equivalent per year $\left(\mathrm{m}\right.$ w.e. $\left.\mathrm{a}^{-1}\right)$ averaged over the mean glacier area,

$b_{n}=\frac{\rho \times \Delta V}{A \times \Delta t}$,

where $\rho$ is the average specific density of ice, $\Delta V$ the volume change, $A$ the average of the initial and final glacier area and $\Delta t$ the time difference in years between the two DEMs. Here we use $\rho=900 \mathrm{~kg} \mathrm{~m}^{-3}$ in order to be consistent with the commonly used value for Icelandic glaciers (e.g. Guðmundsson et al., 2011; Pálsson et al., 2012; Jóhannesson et al., 2013).

The uncertainty related to the conversion of ice volume to mass change to obtain geodetic mass balances is small for long periods (decades) of glacier retreat, and when volume loss is mainly confined to the ablation area, mostly ice is lost (e.g. Huss, 2013). We base our estimates of the error for the geodetic mass balance on previous assessments of errors in DEM reconstruction and geodetic mass balance calculations for ice caps in Iceland (e.g. Guðmundsson et al., 2011), which take into account the square root of the sum of the two errors associated with each DEM and the glacier area. 


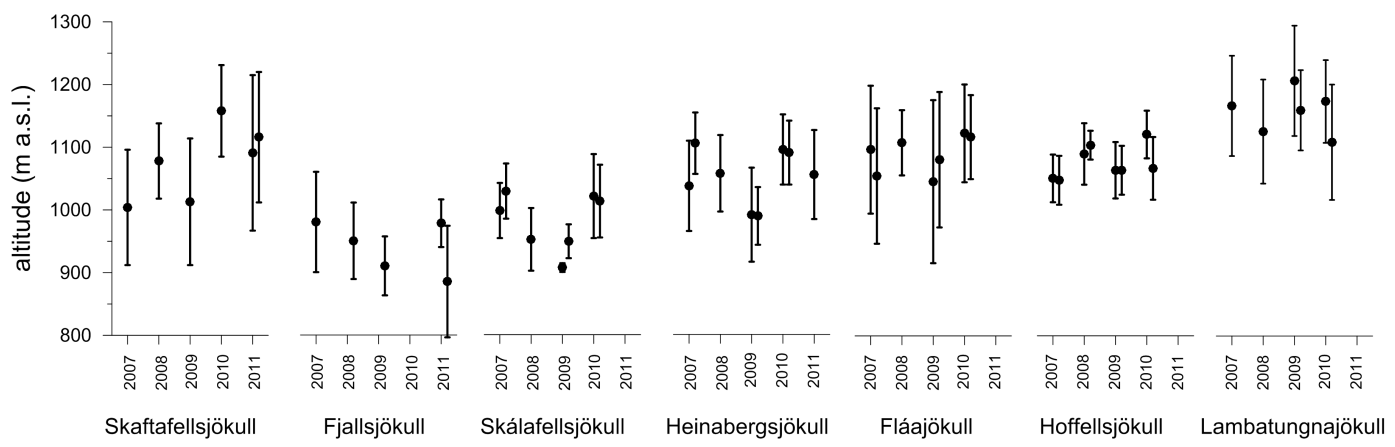

Figure 4. The elevation range (average and standard deviation) of the snowline for each glacier deduced from MODIS images (2007-2011); the elevation obtained from the lidar DEM.

\section{Results}

\subsection{Spatial and temporal variability of the MODIS derived ELA}

Spatial variability is observed in the autumn snowline or the MODIS derived ELA (referred to as the MODISELA hereafter). The average MODIS-ELA and the standard deviation for each year is displayed in Fig. 4. The MODIS-ELA of the western outlet glaciers of Öræfajökull is approximately $170 \mathrm{~m}$ higher than on the eastern outlet glaciers, and the MODIS-ELA rises eastward from Skálafellsjökull to Lambatungnajökull by $\sim 200 \mathrm{~m}$. Due to the low resolution of the MODIS images, the snowline on the narrow outlet glaciers of Öræfajökull (Morsárjökull, Svínafellsjökull, Kotárjökull, Kvíárjökull and Hrútárjökull) is only discernible on a limited number of images. The snowline on the $\sim 2 \mathrm{~km}$ wide Skaftafellsjökull and $\sim 3.5 \mathrm{~km}$ wide Fjallsjökull is detectable on several images, allowing determination of the MODIS-ELA in all years. The MODISELA range and AAR of the narrow outlet glaciers of Öræfajökull, is thus inferred by comparison with the neighbouring glaciers during overlapping years (Table 2). The MODIS-ELA fluctuated about $100-150 \mathrm{~m}$ during this five-year period. A similar interannual trend of the MODISELA is observed; the MODIS-ELA in 2009 is the lowest for most of the glaciers, whereas the MODIS-ELA is usually the highest in 2010 (Fig. 4). The AAR of the outlet glaciers is in the range of 0.43 to 0.71 , but the majority of the outlets have an AAR of 0.6-0.65 (Table 1), which are slightly higher values than reported in e.g. Dyurgerov et al. (2009).

\subsection{Frontal variations and areal change}

The areal extent of the outlet glaciers at different times is shown in Figs. 5 and 6, and in Table 3. The outlets started retreating from their terminal LIA moraines $\sim 1890$ (Hannesdóttir et al., 2014), and had retreated $1-4 \mathrm{~km}$ by 2010 (Figs. 2c and 7). This corresponds to an areal decrease of $164 \pm 6 \mathrm{~km}^{2}$, equal to $16 \%$ of the $\sim 1890$ areal extent, or in the range of $15-30 \%$ for individual glaciers (Table 3 and Fig. 8). For the majority of the glaciers, the rate of area loss was highest during the time period 1904-1945 (Fig. 9a). In the 1960s-1990s, glacial retreat slowed down or halted (Fig. 2c). During the time period 1982/19892002, the areal extent of the glaciers changed little (Figs. 5, 6 and 2c, and Table 3). Morsárjökull, Skaftafellsjökull, Hrútárjökull, Skálafellsjökull and Fláajökull advanced in 1970-1990, others remained stagnant (Fig. 2c). The terminus position of Skálafellsjökull, Heinabergsjökull and Fláajökull was not measured during this time period, but from aerial images of 1979 , it was possible to position their termini, and infer their slight advance during this period (Fig. 2c). The majority of the glaciers started retreating just prior to the turn of the 21st century; between 2002 and 2010 the glaciers experienced high rates of area loss, the highest for Heinabergsjökull and Hoffellsjökull during the last 120 years (Fig. 9a and Table 3).

\subsection{Thinning and volume changes}

Between $\sim 1890$ and 2010 the outlet glaciers lowered by 150-270 m near the terminus, but negligible downwasting was observed above $\sim 1500-1700 \mathrm{~m}$ elevation (Fig. 10a). Svínafellsjökull and Kvíárjökull underwent the smallest surface lowering during this period, and the glaciers only retreated about $1 \mathrm{~km}$ in $\sim 1890-2010$ (Fig. 2c), both terminating in overdeepened basins. Heinabergsjökull, Hoffellsjökull and Lambatungnajökull experienced the greatest downwasting (Fig. 10a), the outlets are constrained by valley walls on both sides, and have retreated close to $3 \mathrm{~km}$ in the post-LIA period (Table 1).

Surface lowering between 1945 and 2010 is shown in Fig. 10b. The comparison of the size of nunataks in the upper reaches of the outlet glaciers reveals negligible surface elevation change above $1300 \mathrm{~m}$ a.s.l. between 1945 and 2010. An example of the different appearance of nunataks of the outcrops of Skaftafellsjökull called "Skeriðmilli skarða" at different times during the 20th century, is shown in Fig. 3. Across the whole southeast part of Vatnajökull, the nunataks 


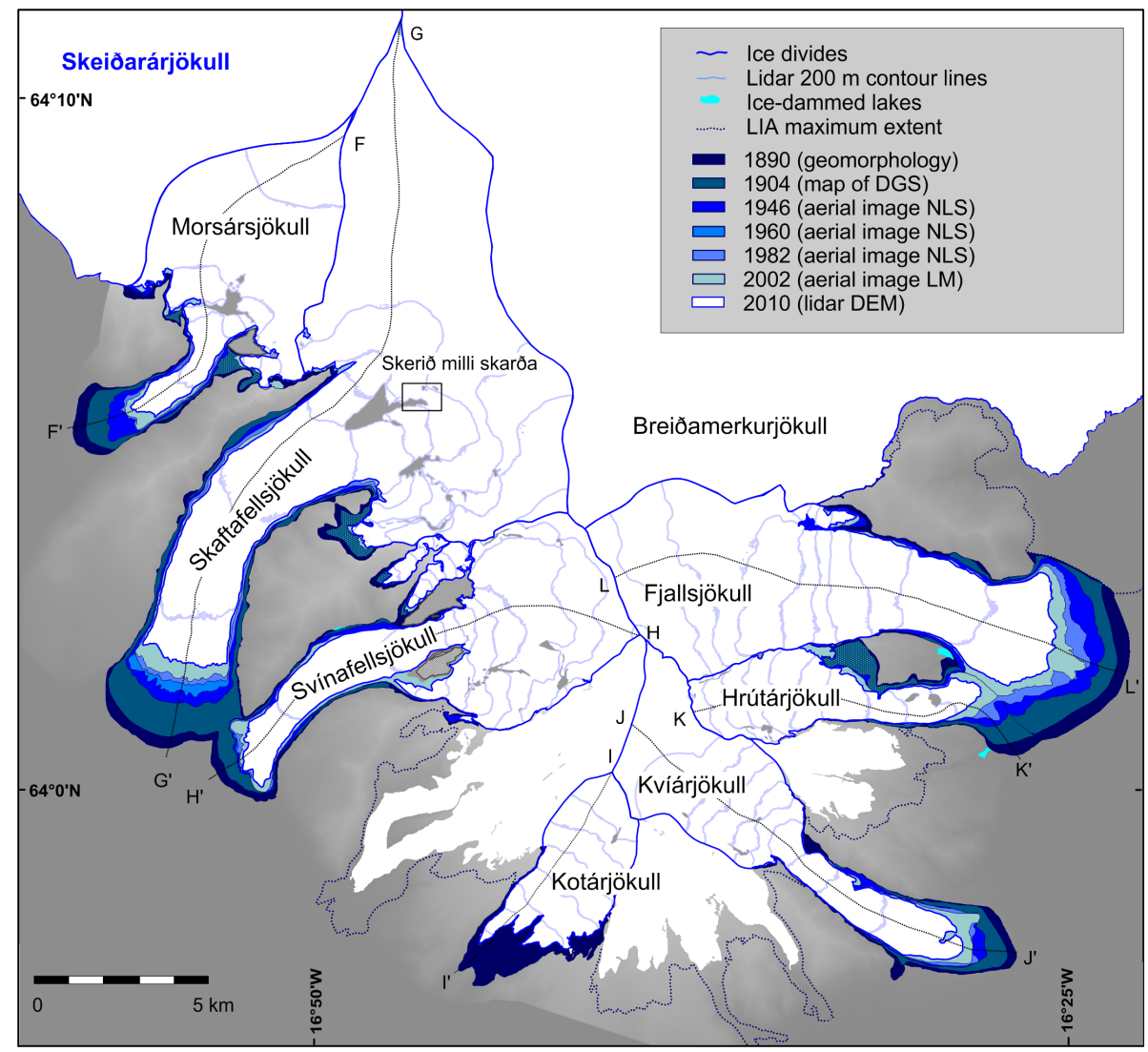

Figure 5. The extent of Öræfajökull's outlet glaciers and Morsárjökull at different times. The surface map is derived from the lidar DEM, showing $200 \mathrm{~m}$ contour lines. The locations of longitudinal profiles shown in Fig. 8 are indicated with capital letters F-F', G-G', etc. The area covering the nunataks east of "Skerið milli skarða", shown in Fig. 3 is outlined. The ice extent in 1904 is uncertain in the mountains surrounding Morsárjökull and Skaftafellsjökull, due to distorted topography on the old map. DGS: Danish General Staff, NLS= National Land Survey of Iceland, LM: Loftmyndir ehf. The 1890 glacier extent is from Hannesdóttir et al. (2014).

are smaller in 1989 and 1982 than in 1945 or 2002, indicating that the glacier was thicker at that time. A slight thickening in the accumulation area between 1945 and 1982/1989 is thus apparent. However, the nunataks were similar in size in 1945 and 2002.

In the time period $\sim 1890-2010$ all the outlets collectively lost $60 \pm 8 \mathrm{~km}^{3}$ (around $22 \%$ of their LIA volume) and the volume loss of individual outlets was in the range of $15-50 \%$ (Table 4 and Fig. 8). The rate of volume loss was highest between 2002 and 2010, and second highest in the time period 1904-1945 (Fig. 9b). All glaciers had lost at least half of their total post-LIA volume loss by 1945 (Table 4). The eastern outlet glaciers (except Lambatungnajökull), experienced higher rates of volume loss than the majority of the smaller and steeper outlets of Öræfajökull ice cap during every period of the last 120 years (Fig. 9b). For example, between 2002 and 2010, the volume loss of the Öræfajökull outlets was in the range of -0.34 to $-0.13 \mathrm{~km}^{3} \mathrm{a}^{-1}$ vs. -0.95 to $-0.28 \mathrm{~km}^{3} \mathrm{a}^{-1}$ of the eastern outlets (Fig. 9b). Since no 1980s DEMs exist for the
Öræfajökull outlets, the comparison with the eastern outlets is restricted to $1945-2002$.

\subsection{Geodetic mass balance}

The average geodetic mass balance of all the studied glaciers was negative during every time interval of the study period (Fig. 11 and Table 5), however it is likely that individual years had positive mass balance. The average mass balance of the outlets $\sim 1890-2010$ was -0.38 m w.e. $\mathrm{a}^{-1}$, and in the range of -0.70 to $-0.32 \mathrm{mw}$.e. $\mathrm{a}^{-1}$ for individual outlets. The mass change in $\sim 1890-1904$ was between -0.5 and $-0.15 \mathrm{~m}$ w.e. $\mathrm{a}^{-1}$. In the first half of the 20th century (1904-1945), the average mass balance was in the range of -1.00 to $-0.50 \mathrm{~m}$ w.e. $\mathrm{a}^{-1}$. The geodetic mass balance during the warmest decade of the 20th century (1936-1945) is only available for Hoffellsjökull and Lambatungnajökull, when the mass balance was -1.00 and $-0.75 \mathrm{~m}$ w.e. $\mathrm{a}^{-1}$, respectively. In 1945-2002, the mass balance returned to similar values as at the turn of the 19th century. The geodetic mass balance of the eastern outlets was similar 


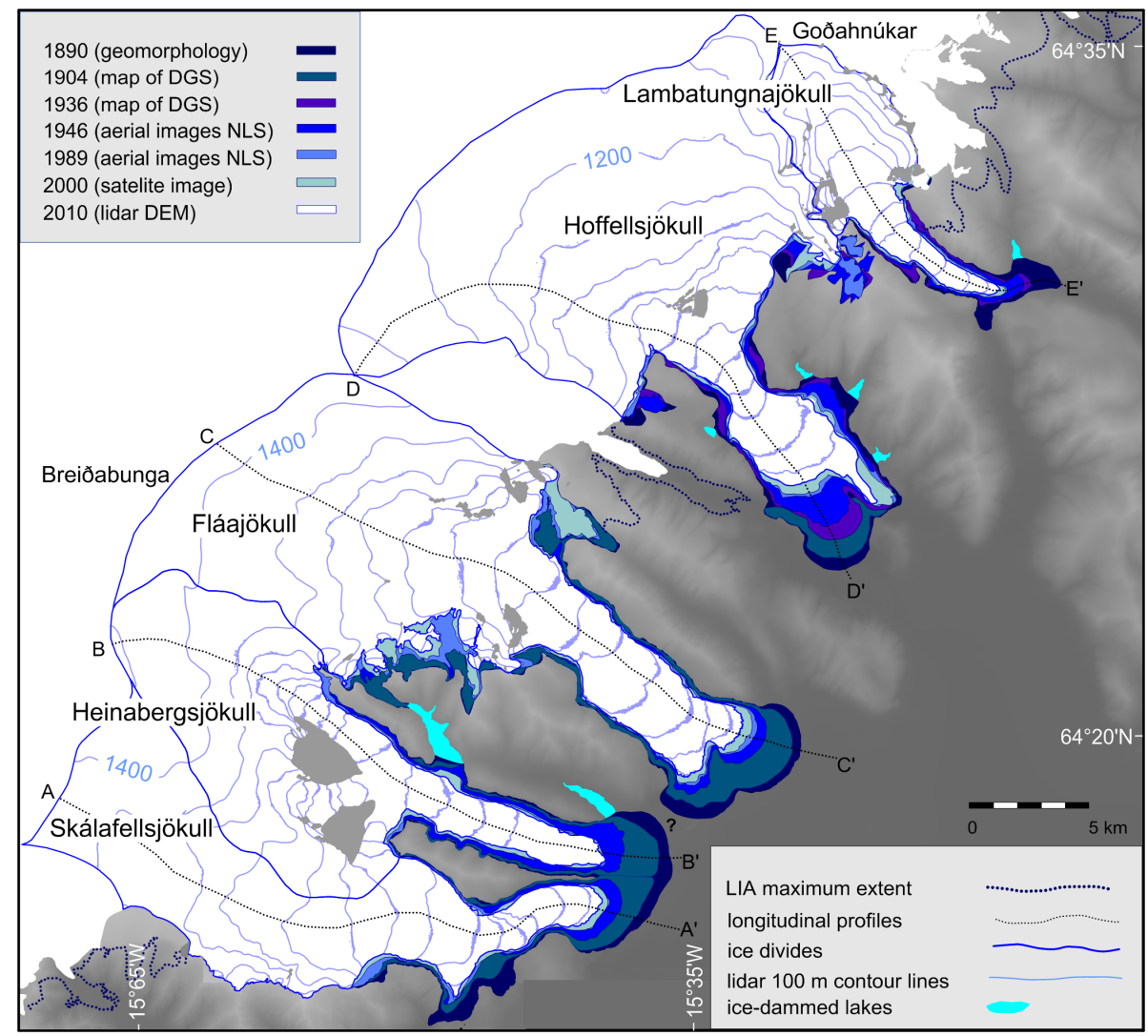

Figure 6. The extent of Skálafellsjökull, Heinabergsjökull, Fláajökull, Hoffellsjökull and Lambatungnajökull at different times. The locations of longitudinal profiles shown in Fig. 8 are indicated with capital letters (A-A', B-B' etc.). Surface map is derived from the lidar DEM, showing $100 \mathrm{~m}$ contour lines. (DGS: Danish General Staff, NLS: National Land Survey of Iceland.) The $\sim 1890$ glacier extent is from Hannesdóttir et al. (2014).

during the periods 1945-1989 and 1989-2002. The most negative balance is estimated in 2002-2010, ranging between -1.50 and $-0.80 \mathrm{~m}$ w.e. $\mathrm{a}^{-1}$, except for Heinabergsjökull $\left(-2.70 \mathrm{~m}\right.$ w.e. $\left.\mathrm{a}^{-1}\right)$.

Of the Öræfajökull outlets, Fjallsjökull and Hrútárjökull experienced the most negative average mass balance during the majority of the time periods (Fig. 11). Heinabergsjökull and Hoffellsjökull sustained the highest rate of mass loss of the eastern outlets during most intervals. Skálafellsjökull and Fláajökull generally had the least negative mass balance during every time period of the post-LIA interval of the eastern outlet glaciers, and Kvíárjökull and Svínafellsjökull of the Öræfajökull outlets.

\subsection{Glacier hypsometry}

The majority of the studied glaciers belong to shape class B (Table 1 and Fig. 12). Lambatungnajökull and Hrútárjökull belong to shape class D. Two glaciers have bimodal hypsometric curves (class E), Svínafellsjökull and Fjallsjökull; the latter could be classified as a piedmont glacier (class C) in its greatest extent $\sim 1890$ (Fig. 12).

\section{Discussion}

\subsection{Glacier changes since the end of the LIA}

The retreat of the outlet glaciers of southeast Vatnajökull from the LIA terminal moraines, which started in the last decade of the 19th century, was not continuous. The recession accelerated in the $1930 \mathrm{~s}$, as a result of the rapid warming beginning in the 1920s (Fig. 2b, c). Similarly enhanced glacier retreat was observed in the Alps and southern Norway in the early 20th century (Zemp et al., 2011, and references therein). Recession of the southeast outlets of Vatnajökull slowed down due to cooler summers after the 1940s, and from the 1960s to late 1980s the glaciers remained stagnant or advanced slightly (Fig. 2c). After 1995, warmer temperatures than in the preceding 23 decades (Fig. 2b) caused retreat of the southeast outlets, which increased after the year 2000 (Björnsson and Pálsson, 2008; Björnsson et al., 2013).

A mass gain in the accumulation area during the cooler period 1960s-1980s was observed on the aerial images of the 1980s, by smaller nunataks than on the 1945 aerial images 


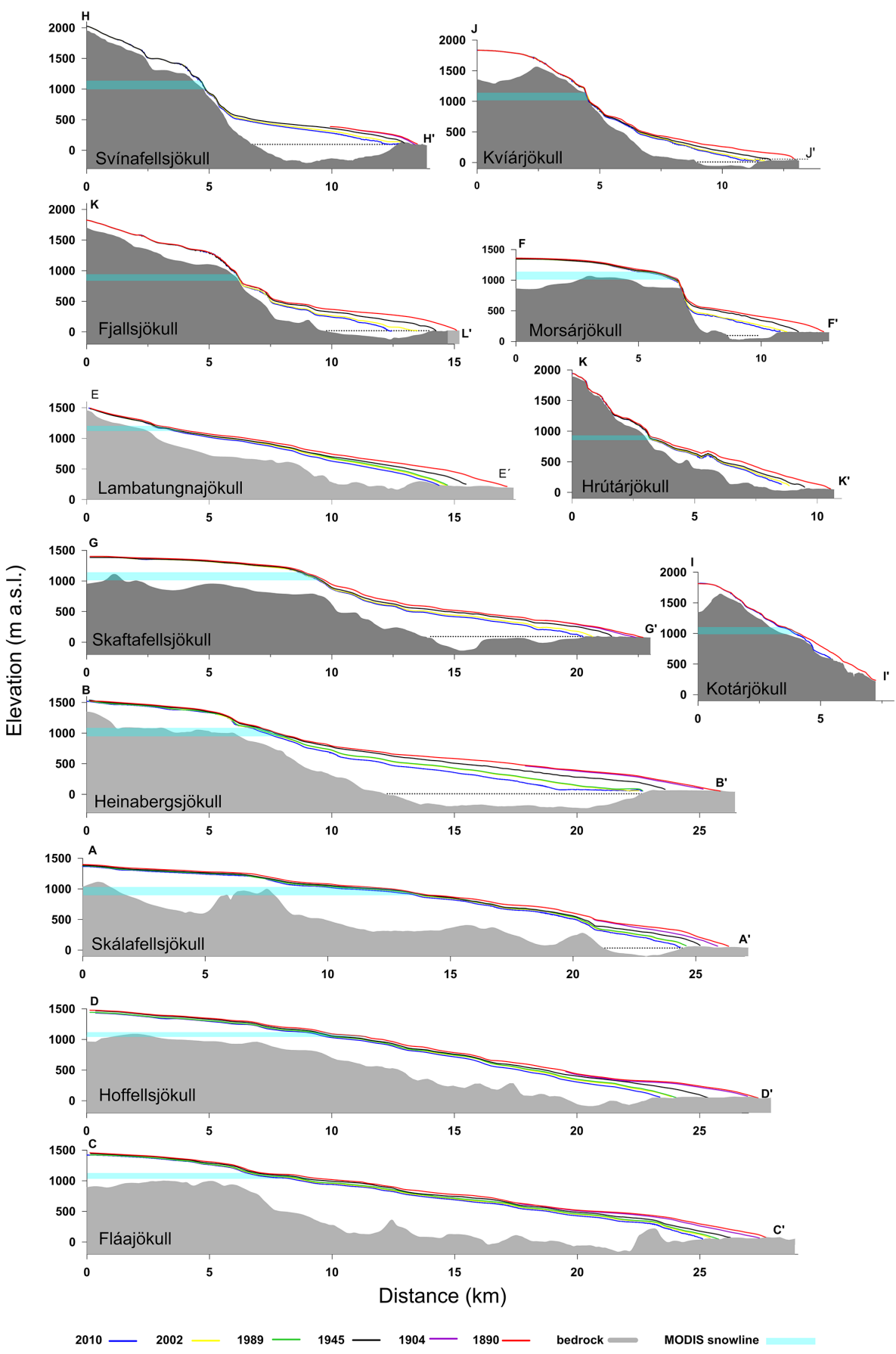

Figure 7. Longitudinal profiles of the southeast outlet glaciers, showing ice thickness and location of the termini at different times. The average ELA derived from the MODIS images is shown with a light blue horizontal line. Öræfajökull outlets with dark grey coloured basal topography and the eastern outlets with light grey coloured basal topography.

(Fig. 3). The mass balance of the outlets in some years of the 1970s and 1980s may have been positive, although the geodetic mass balance of the periods 1945-1989 (for the eastern outlets) and 1945-2002 (for Öræfajökull outlets) was negative (Fig. 11). The mass balance of the larger ice caps in Iceland was generally close to zero in 1980-2000 (e.g.
Björnsson and Pálsson, 2008; Guðmundsson et al., 2009, 2011; Pálsson et al., 2012). In situ measurements show that mass balance was positive on Vatnajökull 1991-1994, but negative since then (Björnsson and Pálsson, 2008; Björnsson et al., 2013). 
Table 3. Area of the outlet glaciers at different times in $\mathrm{km}^{2}$. The estimated error of the glacier margin is shown in parenthesis in the top row. The DMA aerial photographs of Öræfajökull are from 1982, and of the eastern outlet glaciers from 1989. Glacier outlines from 2002 for Öræfajökull (obtained from images of Loftmyndir ehf.), and from 2000 for Skálafellsjökull, Heinabergsjökull, Fláajökull, Hoffellsjökull and Lambatungnajökull (digitized from Landsat satellite images). Ice divides are assumed to remain constant throughout the time period. The numbers for Hoffellsjökull are from Aðalgeirsdóttir et al. (2011). Percentages are relative to the $\sim 1890$ area. $*$ The area of Lambatungnajökull in 1904 is estimated from the relative extent of the neighbouring outlets in that year (99\%). Kotárjökull is not included in the sum of the Öræfajökull outlets, since its area is only known for $\sim 1890$ and 2010.

\begin{tabular}{lllllll}
\hline Glacier & $\begin{array}{l}\sim 1890 \\
(20 \mathrm{~m})\end{array}$ & $\begin{array}{l}1904 \\
(15 \mathrm{~m})\end{array}$ & $\begin{array}{l}1945 \\
(10 \mathrm{~m})\end{array}$ & $\begin{array}{l}1982 / 1989 \\
(10 \mathrm{~m})\end{array}$ & $\begin{array}{l}2002 \\
(5 \mathrm{~m})\end{array}$ & $\begin{array}{l}2010 \\
(2 \mathrm{~m})\end{array}$ \\
\hline Morsárj. & $35.3 \pm 0.7$ & $34.5 \pm 0.6(98 \%)$ & $31.6 \pm 0.3(90 \%)$ & $30.9 \pm 0.4(87 \%)$ & $30.0 \pm 0.2(85 \%)$ & $28.9 \pm 0.1(82 \%)$ \\
Skaftafellsj. & $97.8 \pm 1.3$ & $96.7 \pm 1.0(99 \%)$ & $90.1 \pm 0.6(92 \%)$ & $89.4 \pm 0.6(91 \%)$ & $86.4 \pm 0.3(88 \%)$ & $84.1 \pm 0.1(86 \%)$ \\
Svínafellsj. & $39.5 \pm 0.9$ & $38.9 \pm 0.7(98 \%)$ & $36.1 \pm 0.5(91 \%)$ & $35.5 \pm 0.5(90 \%)$ & $34.8 \pm 0.3(88 \%)$ & $33.2 \pm 0.1(84 \%)$ \\
Kotárj. & $14.5 \pm 0.4$ & & $12.3 \pm 0.5(85 \%)$ & & & $11.5 \pm 0.04(79 \%)$ \\
Kvíárj. & $27.9 \pm 0.7$ & $27.4 \pm 0.5(98 \%)$ & $25.4 \pm 0.4(91 \%)$ & $25.1 \pm 0.3(90 \%)$ & $24.4 \pm 0.2(88 \%)$ & $23.2 \pm 0.1(83 \%)$ \\
Hrútárj. & $17.1 \pm 0.5$ & $16.7 \pm 0.4(98 \%)$ & $14.1 \pm 0.2(83 \%)$ & $13.9 \pm 0.2(81 \%)$ & $13.2 \pm 0.1(77 \%)$ & $12.2 \pm 0.04(71 \%)$ \\
Fjallsj. & $57.7 \pm 0.8$ & $56.1 \pm 0.6(97 \%)$ & $51.7 \pm 0.4(90 \%)$ & $49.4 \pm 0.4(86 \%)$ & $47.3 \pm 0.2(82 \%)$ & $44.6 \pm 0.1(77 \%)$ \\
\hline Öræfaj. & $275.3 \pm 5.3$ & $270.3 \pm 3.8(98 \%)$ & $249.0 \pm 2.4(90 \%)$ & $244.1 \pm 2.4(89 \%)$ & $236.1 \pm 1.3(86 \%)$ & $226.2 \pm 0.58(82 \%)$ \\
\hline Skálafellsj. & $117.9 \pm 1.6$ & $116.4 \pm 1.2(99 \%)$ & $106.6 \pm 0.7(90 \%)$ & $104.0 \pm 0.7(88 \%)$ & $102.8 \pm 0.3(87 \%)$ & $100.6 \pm 0.1(85 \%)$ \\
Heinabergsj. & $120.3 \pm 1.3$ & $118.2 \pm 1.0(98 \%)$ & $109.0 \pm 0.6(91 \%)$ & $102.5 \pm 0.6(85 \%)$ & $101.8 \pm 0.3(85 \%)$ & $100.6 \pm 0.1(83 \%)$ \\
Fláaj. & $205.6 \pm 1.9$ & $202.1 \pm 1.4(98 \%)$ & $184.1 \pm 1.0(90 \%)$ & $181.9 \pm 0.9(88 \%)$ & $177.4 \pm 0.5(86 \%)$ & $169.7 \pm 0.2(83 \%)$ \\
Hoffellsj. & $234.5 \pm 1.9$ & $232.3 \pm 1.4(99 \%)$ & $224.5 \pm 1.1(96 \%)$ & $215.9 \pm 1.0(92 \%)$ & $212.7 \pm 0.5(91 \%)$ & $207.5 \pm 0.2(88 \%)$ \\
Lambatungnaj. & $46.1 \pm 0.9$ & $45.1 \pm 0.9 *$ & $40.9 \pm 0.4(89 \%)$ & $39.4 \pm 0.4(86 \%)$ & $38.8 \pm 0.2(84 \%)$ & $36.3 \pm 0.1(79 \%)$ \\
\hline Eastern & $723.9 \pm 7.6$ & $714.2 \pm 5.9(99 \%)$ & $664.6 \pm 3.8(92 \%)$ & $643.8 \pm 3.6(89 \%)$ & $632.8 \pm 1.8(87 \%)$ & $612.3 \pm 0.7(85 \%)$ \\
\hline
\end{tabular}

1936 area: Hoffellsjökull $227.7 \pm 1.5 \mathrm{~km}^{2}(97 \%)$, Lambatungnajökull $41.9 \pm 0.7 \mathrm{~km}^{2}(91 \%)$.
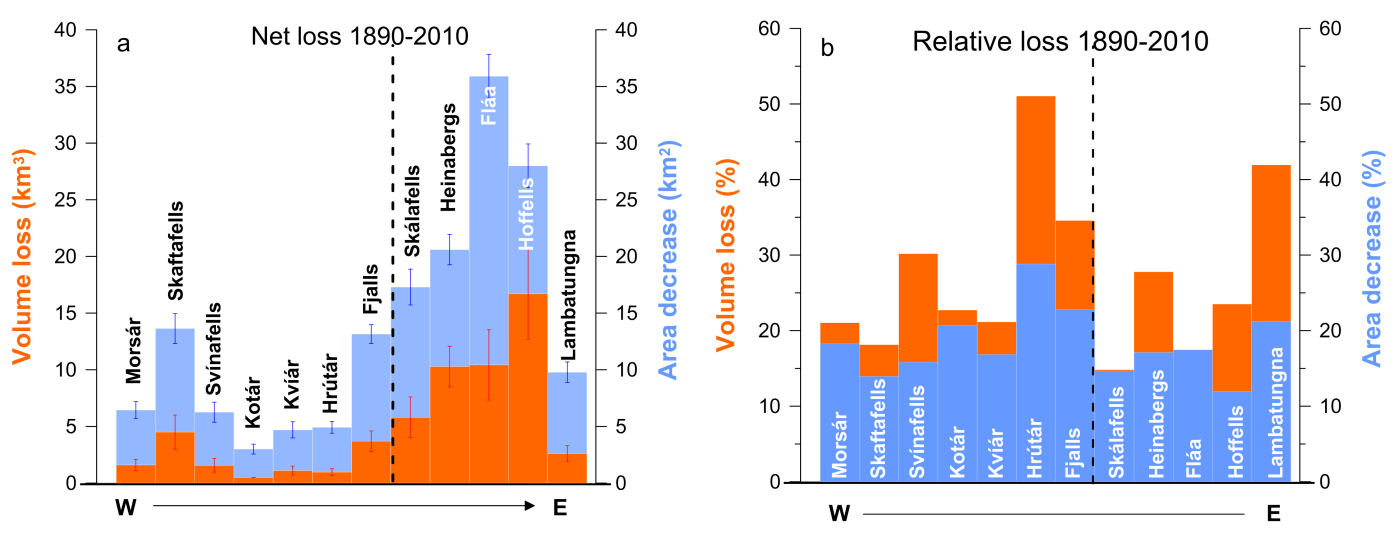

Figure 8. Total area decrease (light blue) and volume loss (orange) during the time period $\sim 1890-2010$ (a) absolute values, and (b) relative to the LIA maximum size. Glaciers represented in geographical order and the dotted line separates the outlets of Öræfajökull and the eastern outlets.

The highest annual rate of volume and mass loss of the periods investigated was observed in 2002-2010 for almost all the outlet glaciers (Figs. 9b and 11, Table 5). The geodetic mass balance in the range of -1.38 to $-1.51 \mathrm{~m}$ w.e. $\mathrm{a}^{-1}$ (apart from Heinabergsjökull) during the time period 20022010 is similar to the measured specific mass balance on the larger ice caps in Iceland in the first decade of the 21 st century, equal to $-1.0 \pm 0.5 \mathrm{~m}$ w.e. $\mathrm{a}^{-1}$ (Pálsson et al., 2012; Björnsson et al., 2013; Jóhannesson et al., 2013). The warming in Iceland since the 1990s has been 3-4 times higher than the average warming of the Northern Hemisphere during the same time interval (Jones et al., 2012; Björnsson et al., 2013), which may explain the high rates of mass loss in the first decade of the 21st century. In situ mass balance measurements of glaciers in Iceland and degree-day mass balance models of selected glaciers indicate that the mass balance is governed by variation in summer ablation (which is strongly correlated with temperature), rather than winter accumulation (Björnsson and Pálsson, 2008; Guðmundsson 
Table 4. Volume of the southeast outlet glaciers derived from glacier surface DEMs and the bedrock DEM at different times in $\mathrm{km}^{3}$. Percentage is relative to the $\sim 1890$ volume. The estimated point accuracy of the elevation is in parenthesis.

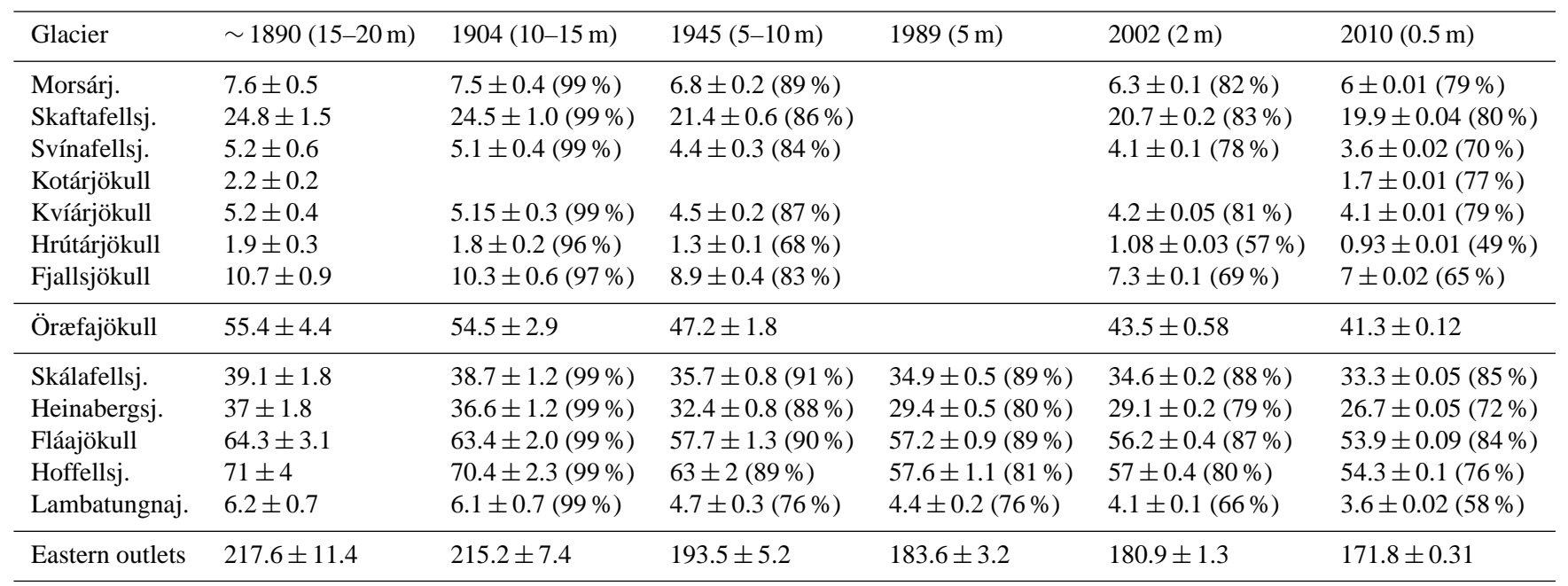

1936 volume: Hoffellsjökull $65 \pm 3 \mathrm{~km}^{3}$ (92\%), Lambatungnajökull $4.9 \pm 0.4 \mathrm{~km}^{3}$ (79\%).

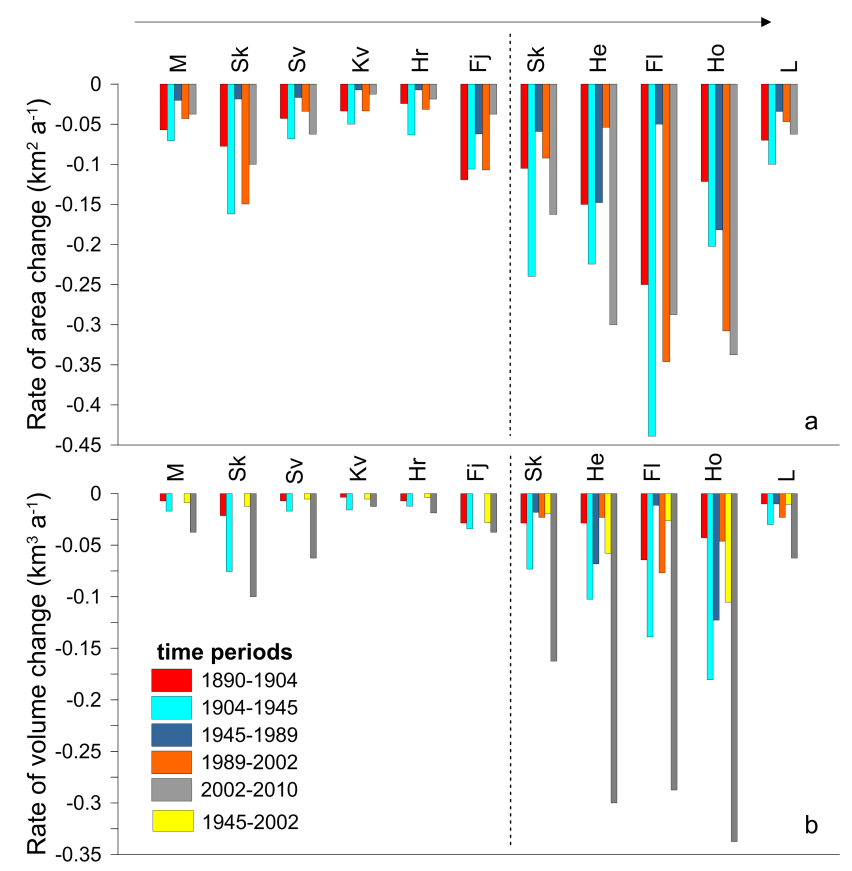

Figure 9. Rate of area (a) and volume (b) change of the outlet glaciers (from west to east) during different time periods of the last 120 years. The first few letters of each glacier name are shown at the top, glaciers represented from west to east. The dotted line separates the outlets of Öræfajökull and the eastern outlets.

et al., 2009, 2011; Pálsson et al., 2012; Björnsson et al., 2013).
Increasing negative mass balance in recent years on the majority of ice sheets, ice caps and glaciers worldwide has been reported (Vaughan et al., 2013, and references therein). Glaciers in Iceland experienced among the most negative mass balance worldwide in the early 21 st century (Vaughan et al., 2013; Gardner et al., 2013). In this time period increased surface lowering on the southeast outlets of Vatnajökull is evidenced in emerging rock outcrops and expansion of nunataks up to an elevation of approximately $1200 \mathrm{~m}$. A pattern of increased downwasting in the accumulation areas in recent years has been observed in Alaska (Cox and March, 2004), the Alps (Paul et al., 2004), North Cascade glaciers (Pelto, 2010), and Svalbard (James et al., 2012).

The ice volume loss (in $\mathrm{km}^{3}$ ) of the non-surging outlets of southeast Vatnajökull $\sim 1890-2010$ corresponds to the ice volume loss of both Langjökull (equal to a mass balance of $-0.45 \mathrm{~m}$ w.e. $\mathrm{a}^{-1}$ ) and Breiðamerkurjökull (equal to $-0.64 \mathrm{~m}$ w.e. $\mathrm{a}^{-1}$ ) during the same time interval (Pálsson et al., 2012; Guðmundsson, 2014). For comparison the glaciers in the Alps have lost $96 \pm 13 \mathrm{~km}^{3}$ (equal to a mass balance of $-0.31 \mathrm{~m}$ w.e. $\mathrm{a}^{-1}$ ) since 1900 (Huss, 2012), similar to the mass loss of the Northern Patagonian Icefield since 1870 (Glasser et al., 2011).

\subsection{Different response to similar climate forcing}

The meteorological records from Hólar in Hornafjörður and Fagurhólsmýri (Fig. 1) indicate similar temperature and precipitation fluctuations during the 20th and early 21 st century at both stations since the start of measurements (Fig. 2a, b). We thus infer that the studied outlets experienced 
Table 5. Geodetic mass balance in $\mathrm{m}$ w.e. $\mathrm{a}^{-1}$ for outlets of Öræfajökull (upper panel) and the eastern outlet glaciers (lower panel) for different time intervals.

\begin{tabular}{|c|c|c|c|c|c|c|c|}
\hline Öræfaj. & $\sim 1890-1904$ & 1904-1945 & & 1945-2002 & & $2002-2010$ & $\sim 1890-2010$ \\
\hline Morsárj. & $-0.18 \pm 0.63$ & $-0.48 \pm 0.15$ & & $-0.26 \pm 0.06$ & & $-0.99 \pm 0.12$ & $-0.37 \pm 0.96$ \\
\hline Skaftaf. & $-0.19 \pm 0.63$ & $-0.73 \pm 0.15$ & & $-0.13 \pm 0.06$ & & $-1.06 \pm 0.12$ & $-0.40 \pm 0.96$ \\
\hline Svínaf. & $-0.1 \pm 0.63$ & $-0.46 \pm 0.15$ & & $-0.2 \pm 0.06$ & & $-0.89 \pm 0.12$ & $-0.32 \pm 0.96$ \\
\hline Kviárj. & $-0.12 \pm 0.63$ & $-0.54 \pm 0.15$ & & $-0.17 \pm 0.06$ & & $-0.8 \pm 0.12$ & $-0.34 \pm 0.96$ \\
\hline Hrútárj. & $-0.27 \pm 0.63$ & $-0.77 \pm 0.15$ & & $-0.24 \pm 0.06$ & & $-1.33 \pm 0.12$ & $-0.5 \pm 0.96$ \\
\hline Fjallsj. & $-0.41 \pm 0.63$ & $-0.6 \pm 0.15$ & & $-0.48 \pm 0.06$ & & $-1.27 \pm 0.12$ & $-0.57 \pm 0.96$ \\
\hline Eastern & $\sim 1890-1904$ & 1904-1945 & $1936-1945$ & 1945-1989 & 1989-2002 & 2002-2010 & $\sim 1890-2010$ \\
\hline Skálaf. & $-0.24 \pm 0.63$ & $-0.58 \pm 0.15$ & & $-0.27 \pm 0.08$ & $-0.25 \pm 0.19$ & -1.38 & -0.40 \\
\hline Heinab. & $-0.22 \pm 0.63$ & $-0.81 \pm 0.15$ & & $-0.56 \pm 0.08$ & -0.36 & $-2.6 \pm 0.12$ & $-0.70 \pm 0.96$ \\
\hline Fláaj. & $-0.28 \pm 0.63$ & $-0.65 \pm 0.15$ & & $-0.42 \pm 0.08$ & $-0.4 \pm 0.19$ & $-1.51 \pm 0.12$ & $-0.42 \pm 0.96$ \\
\hline Hoff. & $-0.16 \pm 0.63$ & $-0.71 \pm 0.15$ & $-0.88 \pm 0.39$ & $-0.46 \pm 0.08$ & $-0.35 \pm 0.19$ & $-1.45 \pm 0.12$ & $-0.57 \pm 0.96$ \\
\hline Lambat. & $-0.14 \pm 0.63$ & $-0.6 \pm 0.15$ & $-0.68 \pm 0.39$ & $-0.17 \pm 0.08$ & $-0.48 \pm 0.19$ & $-1.5 \pm 0.12$ & $-0.47 \pm 0.96$ \\
\hline
\end{tabular}

1904-1936 mass balance: Hoffellsjökull $-0.66 \pm 0.39 \mathrm{~m}$ w.e $\mathrm{a}^{-1}$, Lambatungnajökull $-0.51 \pm 0.39 \mathrm{~m}^{\mathrm{w} . e \mathrm{a}^{-1}}$.
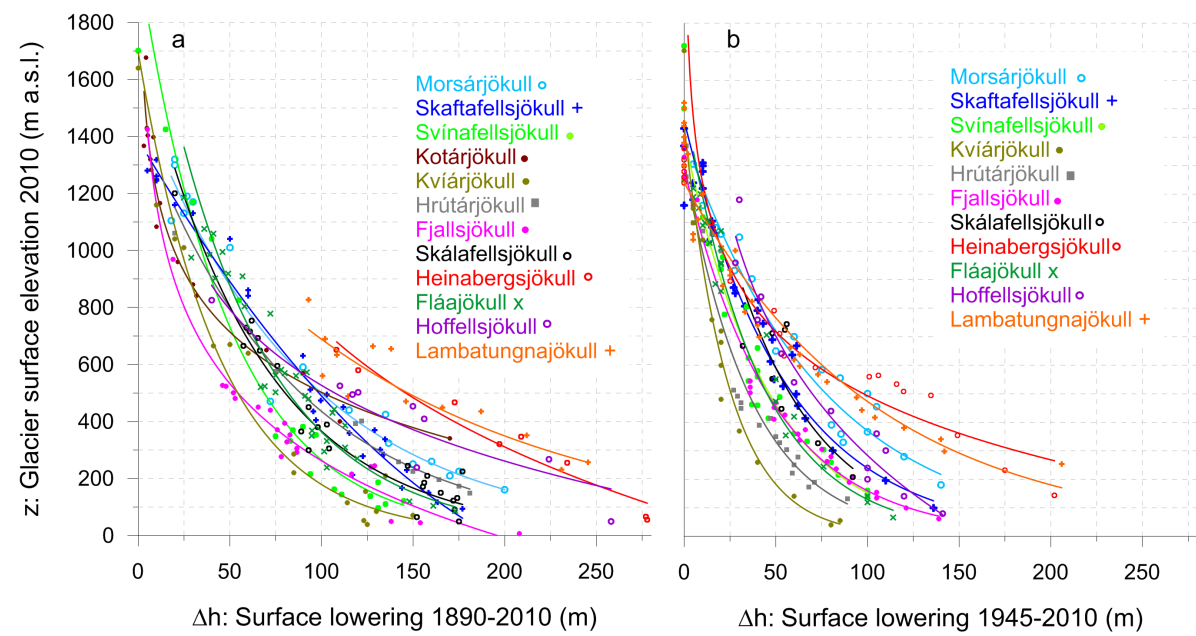

Figure 10. Average surface lowering of every $20 \mathrm{~m}$ altitudinal interval of the outlets of southeast Vatnajökull. (a) Between $\sim 1890$ and 2010 (modified from Hannesdóttir et al., 2014). The 1890 glacier surface elevation in the accumulation area is derived from historical photographs, survey elevation points on the 1904 maps and the aerial images of Loftmyndir ehf., and in the ablation area it is mainly deduced from glacial geomorphological features. (b) Between 1945 and 2010. The glacier surface lowering in the accumulation area is based on comparison of the size of nunataks as observed on the original aerial images of 1945 and the lidar DEMs. No 1945 DEM is available for Kotárjökull.

similar temperature and precipitation forcing since the end of the LIA.

Details in the response or the magnitude of volume loss of the southeast outlet glaciers of Vatnajökull is governed by the hypsometry, overdeepenings and proglacial lakes, but the general response is governed by the climate. Glaciers respond to mass balance changes by adjusting their surface elevation and area. Our results show that glaciers with different hypsometry respond differently to similar climate forcing, as has been reported from several studies (e.g. Kuhn et al., 1985; Oerlemans et al., 1998; Oerlemans, 2007; Jiskoot et al., 2009; Davies et al., 2012; De Angelis, 2014). The appearing proglacial lakes modify the glacier dynamics by floating of the terminus, increasing calving and ice flow, and accelerating the terminus retreat. However, the scarcity of measurements limits the possibility of assessing the relative importance of the overall ice loss (see Trussel et al. (2013) and references therein). Glacier surface lowering is generally a function of elevation (Fig. 10) as detailed previously in Schwitter and Raymond (1993), but the downwasting near the terminus of the southeast outlet glaciers of Vatnajökull is highly variable (Fig. 10). The outlets terminating in overdeepened basins seem to lose mass by thinning rather than retreat, as has been shown to be the retreat pattern 


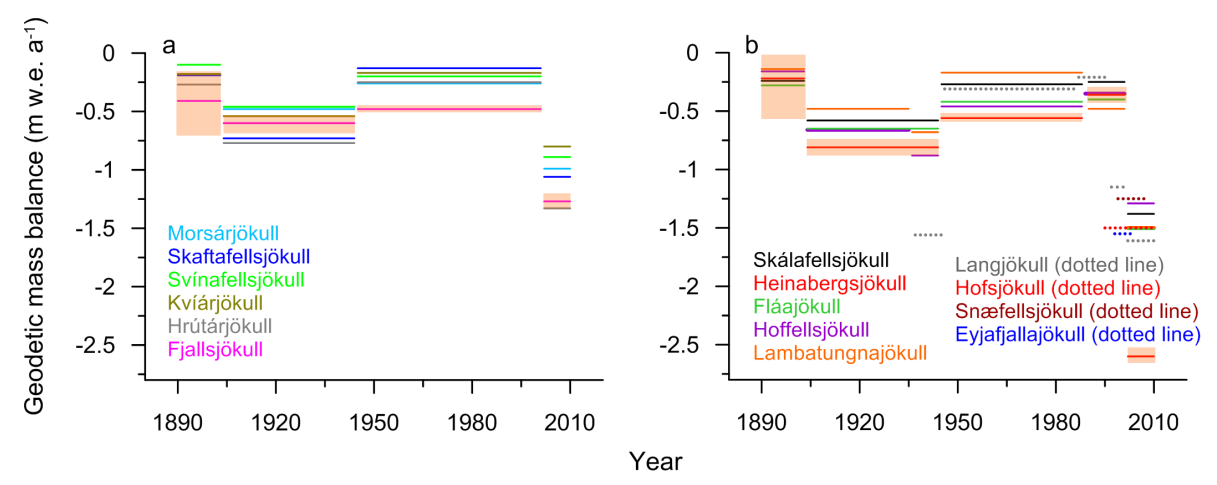

Figure 11. Geodetic mass balance rates during different time periods of the last 120 years. (a) The outlet glaciers of Öræfajökull and Morsárjökull. (b) The eastern outlet glaciers. For comparison, the geodetic mass balance of Langjökull (Pálsson et al., 2012), Eyjafjallajökull 1998-2004 (Guðmundsson et al., 2011), Snæfellsjökull 1999-2008 (Jóhannesson et al., 2011), and Hofsjökull 1995-2010 (Jóhannesson et al., 2013) is presented with dotted lines in (b). The two latest time periods of Langjökull (1997-2002 and 2002-2010) are based on surface mass balance measurements (data base Glaciological group Institute of Earth Sciences, University of Iceland). For error estimates of the geodetic mass balance see Table 5, only the error bars for Fjallsjökull and Heinabergsjökull are shown here.

in overdeepened basins by simplified dynamical models (Adhikari and Marshall, 2013).

The hypsometry of a glacier controls its sensitivity to a rise in the ELA. For example, a temperature rise of $0.5-1.0^{\circ} \mathrm{C}$ would raise the ELA by approximately $100 \mathrm{~m}$ (given a temperature lapse rate). A rise in the ELA will have more effect on the gently sloping eastern outlets, compared to the steeper Öræfajökull outlets. A $100 \mathrm{~m}$ rise in ELA would cause Lambatungnajökull to lose most of its accumulation area, Hoffellsjökull and Morsárjökull would lose approximately 30 and $45 \%$, respectively, whereas the accumulation area of Fjallsjökull would only decrease by 7\%. The ELA during the LIA maximum around 1890 has been determined from the elevation of the highest up-valley lateral LIA moraines of the studied glaciers (Hannesdóttir et al. (2014), see Fig. 12), applying a method known as MELM (maximum elevation of lateral moraines (e.g. Hawkins, 1985). The ELA of the outlets of southeast Vatnajökull has risen by $>300 \mathrm{~m}$ since the end of the LIA (Fig. 12), reducing the size of the accumulation area by $2-$ $16 \%$ (Table 1).

Glaciers of shape class B lost the smallest percentage of their $\sim 1890$ volume (15-20\%). The two glaciers belonging to shape class $\mathrm{B}$, which terminate in proglacial lakes (Heinabergsjökull and Hoffellsjökull) lost 30 and 25\%, respectively, the former has an overdeepened basin reaching 200-300 m b.s.l. (below sea level) (Fig. 7). Fjallsjökull and Hrútárjökull, the east-facing Öræfajökull outlets, lost the most of their $\sim 1890$ volume, or 35 and $50 \%$, respectively, receive a large amount of precipitation and have ice divides lying above $1800 \mathrm{~m}$. The former belongs to shape class E and was terminating in a proglacial lake that was formed as early as 1945 , in the overdeepened basin, and the latter is of shape class D and its debris covered terminus may have increased the ablation. Hrútárjökull and Lambatungnajökull (shape class D) have lost the highest percentage of their $\sim 1890$ volume (Fig. 12).

There is a noticeable difference in the response of the neighbouring outlet glaciers, Skaftafellsjökull and Svínafellsjökull. The former retreated $2.7 \mathrm{~km}$ and lost $20 \%$ of its $\sim 1890$ volume, whereas the latter only retreated $0.8 \mathrm{~km}$ and lost $30 \%$ of its $\sim 1890$ volume. However, part of the surface lowering may be due to excavation of the bed, creating an overdeepening in the terminus area of the glacier, as is well observed for Breiðamerkurjökull (Björnsson, 1996). A similar difference is observed between Skálafellsjökull and Heinabergsjökull, where the former glacier lost $15 \%$ of its $\sim 1890$ volume and retreated $2 \mathrm{~km}$, and the latter lost $30 \%$ of its $\sim 1890$ volume and retreated $3 \mathrm{~km}$. Their basal topography is different, with Heinabergsjökull terminating in an overdeepened basin (Fig. 7), and part of the surface lowering in the ablation area of Heinabergsjökull may likewise be attributed to excavation of the bed. The influence of overdeepenings on the ablation and terminus retreat is clearly seen in the western and eastern arm of Hoffellsjökull (Aðalgeirsdóttir et al., 2011), where the western arm has retreated more than $3 \mathrm{~km}$, whereas the thicker and more excavated eastern arm has only retreated a few hundred $\mathrm{m}$ since $\sim 1890$.

A clearer distinction between the response of the Öræfajökull outlets and the eastern outlets to the post-LIA climate variation would perhaps be expected, as steeper glaciers generally respond faster to changes in climate (e.g. Cuffey and Paterson, 2010). The thinner Öræfajökull glaciers, with ice divides lying 400-500 $\mathrm{m}$ higher than the eastern outlet glaciers and steep mass balance gradient, are expected to have a shorter response time. The response time of a glacier, i.e. the time it takes for a glacier to adjust its geometry to a new steady state after a change in mass balance, is a function of its mean thickness and terminus 

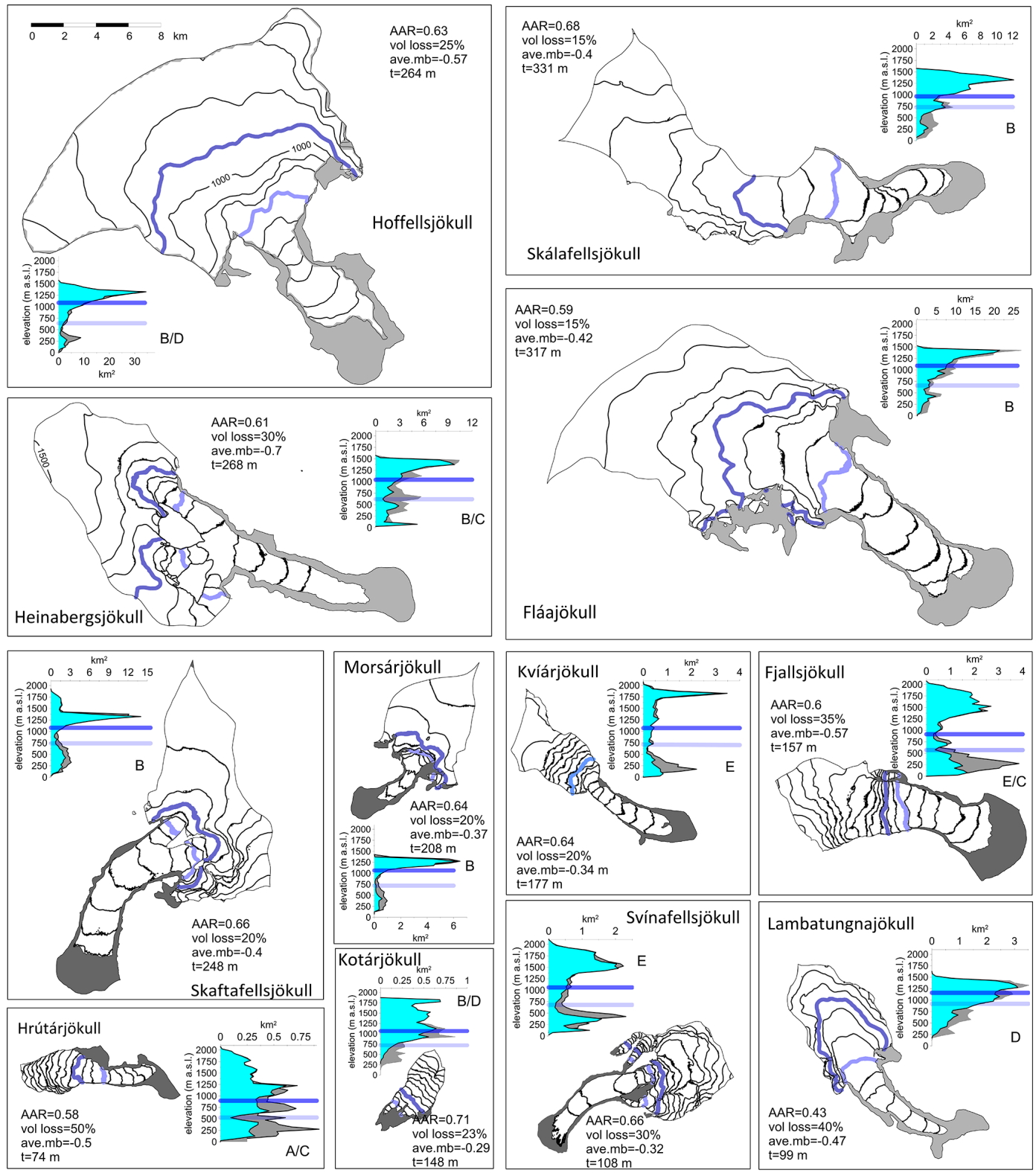

Figure 12. The topography of the outlet glaciers in 2010 with $100 \mathrm{~m}$ contour lines of the lidar DEM. The $\sim 1890$ areal extent is shown in dark grey for the Öræfajökull outlets and in light grey for the eastern outlets. The average MODIS-derived ELA (2007-2011) is drawn in dark blue on the map, and the inferred ELA of the maximum LIA in light blue (Hannesdóttir et al., 2014). Inset graphs show the 2010 area-altitude distribution of the glaciers (hypsometry) in 2010 (cyan) and $\sim 1890$ (grey), with the average ELA for 2010 and $\sim 1890$ shown in dark blue and light blue, respectively. The AAR, the relative volume loss of their $\sim 1890$ size, the average geodetic mass balance $\sim 1890-2010$ is shown in $\mathrm{m}$ w.e. $\mathrm{a}^{-1}$, as well as the average ice thickness $(t)$ in 2010 , for every glacier.

ablation (Jóhannesson et al., 1989), and of its hypsometry and mass balance gradient (Cuffey and Paterson, 2010).

However, the geodetic mass balance records and terminus fluctuations of the outlets of southeast Vatnajökull do not indicate a distinct difference in the response of the outlets of the two glaciated regions. The temporal resolution of the geodetic mass balance records is lower than the supposed response time of $15-30$ years (given terminus ablation of
$-10 \mathrm{~m}$ w.e. $\mathrm{a}^{-1}$ and average ice thicknesses of $150-300 \mathrm{~m}$ ). In order to detect mass balance changes during the colder period following the 1960s, aerial images could be used to construct surface DEMs, and thereby increase the temporal resolution of the mass balance record for the period 19451989 (eastern outlets) or 1945-2002 (Öræfajökull outlets). 


\section{Conclusions}

A series of glacier outlines and glacier surface DEMs for the outlets of southeast Vatnajökull were compiled from various sources. The multi-temporal glacier inventory of volume and area changes for the period $\sim 1890-2010$ is unique. The mass balance history of one of the most sensitive glaciated areas in the world for the post-LIA period was derived by geodetic methods. The average mass balance during the period $1890-2010$ was $-0.38 \pm 0.96 \mathrm{~m}$ w.e. $\mathrm{a}^{-1}$ and these glaciers experienced among the highest mass loss rates (on average $1.34 \mathrm{mw}$ w.e. $\mathrm{a}^{-1}$ ) worldwide in the early 21st century (Vaughan et al., 2013). The glaciated area decreased by $164 \pm 6 \mathrm{~km}^{2}(16 \%)$ in $\sim 1890-2010$, and the outlets collectively lost $60 \pm 8 \mathrm{~km}^{3}$ (22\%) of ice, contributing $0.15 \pm 0.02 \mathrm{~mm}$ to sea-level rise in the post-LIA period.

Each glacier lost between 15 and $50 \%$ of their $\sim 1890$ volume, the difference attributed to their variable hypsometry, the basal topography, and the presence of proglacial lakes, that enhance melting at the terminus. The different response of glaciers experiencing similar climatic forcing underlines the importance of a large sample of glaciers when interpreting the climate signal. The results highlight once more the effect of glacier hypsometry and geometry on the dynamic response of glaciers to changes in mass balance. The different response of the glaciers show that frontal variations and area changes only provide limited information on the glacier response, as some experience rapid downwasting but little retreat. The steep Öræfajökull outlet glaciers are more likely to survive future warming, since their ice divides are 400-500 $\mathrm{m}$ higher than the eastern outlets. Furthermore, proglacial lakes will increase in size and new will form as the glaciers retreat, and cause enhanced melt.

This glacier inventory provides information that can be used to calibrate mass balance-ice flow models that simulate future glacier response to climate scenarios. Work is already underway to simulate the 20th century evolution of three of the eastern outlets.

Acknowledgements. This work was funded by a doctoral grant of the Research Fund of the University of Iceland to Hrafnhildur Hannesdóttir, two additional grants from the University Research Fund to Guðfinna Aðalgeirsdóttir, the Icelandic Road Administration, The Nordic Centre of Excellence SVALI, the Kvísker Fund, the University of Iceland's Research Centre in Hornafjörður, and the Directorate of Labour. We thank Trausti Jónsson at the Icelandic Meteorological Office for access to the temperature and precipitation records. The 2010 lidar DEM was acquired as a part of an ongoing collective effort between the Icelandic Meteorological Office and the Institute of Earth Sciences of the University of Iceland, to map the surface topography of Icelandic ice caps, initiated in the International Polar Year 20072009. We thank Tómas Jóhannesson for very helpful comments on an early draft of the manuscript. Constructive comments from Hester Jiskoot and an anonymous reviewer improved the manuscript. This publication is contribution No. 42 of the Nordic Centre of Excellence SVALI, "Stability and Variations of Arctic Land Ice", funded by the Nordic Top-level Research Initiative (TRI).

Edited by: J. O. Hagen

\section{References}

Aðalgeirsdóttir, G., Guðmundsson, G. H., and Björnsson, H.: Volume sensitivity of Vatnajökull Ice Cap, Iceland, to perturbations in equilibrium line altitude, J. Geophys. Res.-Earth, 110, F04001, doi:10.1029/2005jf000289, 2005.

Aðalgeirsdóttir, G., Jóhannesson, T., Björnsson, H., Pálsson, F., and Sigurðsson, O.: Response of Hofsjökull and southern Vatnajökull, Iceland, to climate change, J. Geophys. Res.-Earth, 111, F03001, doi:10.1029/2005JF000388, 2006.

Aðalgeirsdóttir, G., Guðmundsson, S., Björnsson, H., Pálsson, F., Jóhannesson, T., Hannesdóttir, H., Sigurðsson, S. P., and Berthier, E.: Modelling the 20th and 21st century evolution of Hoffellsjökull glacier, SE-Vatnajökull, Iceland, The Cryosphere, 5, 961-975, doi:10.5194/tc-5-961-2011, 2011.

Adhikari, S. and Marshall, S. J.: Influence of high-order mechanics on simulation of glacier response to climate change: insights from Haig Glacier, Canadian Rocky Mountains, The Cryosphere, 7, 1527-1541, doi:10.5194/tc-7-1527-2013, 2013.

Ahlmann, H. W. and Thorarinsson, S.: Vatnajökull, Scientific results of the Swedish-Icelandic investigations 1936-37-38, Esselte, Stockholm, 1943.

Army Map Service, C. O. E.: Series C762, sheets: 6018-I, IV, 6019I, II, III, IV, 6020-I, II, III, 611IV, 6120-I, II, III, US Army, Washington, D.C., 1950-1951.

Árnadóttir, T., Lund, B., Jiang, W., Geirsson, H., Björnsson, H., Einarsson, P., and Sigurðsson, T.: Glacial rebound and plate spreading: results from the first countrywide GPS observations in Iceland, Geophys. J. Int., 177, 691-716, doi:10.1111/j.1365246X.2008.04059.x, 2009.

Auriac, A., Spaans, K. H., Sigmundsson, F., Hooper, A., Schmidt, P., and Lund, B.: Iceland rising: Solid Earth response to ice retreat inferred from satellite radar interferometry and visocelastic modeling, J. Geophys. Res.-Sol. Ea., 118, 13311344, doi:10.1002/Jgrb.50082, 2013.

Auriac, A., Sigmundsson, F., Hooper, A., Spaans, K. H., Björnsson, H., Pálsson, F., Pinel, V., and Feigl, K. L.: InSAR observations and models of crustal deformation due to glacial surge in Iceland, Geophys. J. Int., 198, 1329-1341, doi:10.1093/gji/ggu205, 2014.

Barcaza, G., Aniya, M., Matsumoto, T., and Aoki, T.: SatelliteDerived Equilibrium Lines in Northern Patagonia Icefield, Chile, and Their Implications to Glacier Variations, Arct. Antarct. Alp. Res., 41, 174-182, doi:10.1657/1938-4246-41.2.174, 2009.

Bauder, A., Funk, M., and Huss, M.: Ice-volume changes of selected glaciers in the Swiss Alps since the end of the 19th century, Ann. Glaciol., 46, 145-149, 2007.

Berthier, E., Le Bris, R., Mabileau, L., Testut, L., and Remy, F.: Ice wastage on the Kerguelen Islands (49 degrees S, 
69 degrees E) between 1963 and 2006, J. Geophys. Res.-Earth, 114, doi:10.1029/2008JF001192, 2009.

Björnsson, H.: Glaciers in Iceland, Jökull, 29, 74-80, 1979.

Björnsson, H.: Scales and rates of glacial sediment removal: a $20 \mathrm{~km}$ long and $300 \mathrm{~m}$ deep trench created beneath Breiðamerkurjökull during the Little Ice Age, Ann. Glaciol., 22, 141-146, 1996.

Björnsson, H.: Jöklar á Íslandi, Opna, Reykjavík, 2009.

Björnsson, H., and Pálsson, F.: Icelandic glaciers, Jökull, 58, 365$386,2008$.

Björnsson, H., and Pálsson, F.: Jöklar í Hornafirði, rannsóknir og saga, in: Jöklaveröld, Náttúra og Mannlíf, edited by: Björnsson, H., Skrudda, Reykjavík, 125-164, 2004.

Björnsson, H., Pálsson, F., Sigurðsson, O., and Flowers, G. E.: Surges of glaciers in Iceland, Ann. Glaciol., 36, 82-90, 2003.

Björnsson, H., Pálsson, F., Guðmundsson, S., Magnússon, E., Aðalgeirsdóttir, G., Jóhannesson, T., Berthier, E., Sigurðsson, O., and Thorsteinsson, T.: Contribution of Icelandic ice caps to sea level rise: Trends and variability since the Little Ice Age, Geophys. Res. Lett., 40, 1546-1550, doi:10.1002/Grl.50278, 2013.

Böðvarsson, A.: Landmælingar og kortagerð Dana á Íslandi: Upphaf landmælinga á Íslandi, Landmælingar Íslands, Reykjavík, 1996.

Church, J. A., Clark, P. U., Cazenave, A., Gregory, J. M., Jevrejeva, S., Levermann, A., Merrifield, M. A., Milne, G. A., Nerem, R. S., Nunn, P. D., Payne, A. J., Pfeffer, W. T., Stammer, D., and Unnikrishnan, A. S.: Sea level change, in: Climate Change 2013: The Physical Science Basis. Contribution of Working Group I to the Fifth Assessment Report of the Intergovernmental Panel on Climate Change, edited by: Stocker, T. F., Qin, D., Plattner, G.-K., Tignor, M., Allen, S. K., Boschung, J., Nauels, A., Xia, Y., Bex, V., and Midgley, P. M., Cambridge University Press, Cambridge, UK and New York, NY, USA, 2013.

Cox, L. H. and March, R. S.: Comparison of geodetic and glaciological mass-balance techniques, Gulkana Glacier, Alaska, USA, J. Glaciol., 50, 363-370, doi:10.3189/172756504781829855, 2004.

Cuffey, K. M. and Paterson, W. S. B.: The Physics of Glaciers, 4th Edn., Elsevier, Burlington, 2010.

Danish General Staff: Sheets: 87-NV, SV, SA, 97-NV, NA, 96-NA, Generalstabens Topografiske Afdeling, Copenhagen, 1904.

Davies, B. J., Carrivick, J. L., Glasser, N. F., Hambrey, M. J., and Smellie, J. L.: Variable glacier response to atmospheric warming, northern Antarctic Peninsula, 1988-2009, The Cryosphere, 6, 1031-1048, doi:10.5194/tc-6-1031-2012, 2012.

De Angelis, H.: Hypsometry and sensitivity of the mass balance to changes in equilibrium-line-altitude: the case of the Southern Patagonia Icefield, J. Glaciol., 60, 14-28, doi:10.3189/2014JoG13J127, 2014.

Defense Mapping Agency, H. C.: Series C761, sheets: 2113-I,2213I,III,IV,2214-II,III, National Land Survey of Iceland, Reykjavík, 1997.

De Woul, M., and Hock, R.: Static mass-balance sensitivity of Arctic glaciers and ice caps using a degree-day approach, Ann. Glaciol., 42, 217-224, doi:10.3189/172756405781813096, 2005 .
Dyurgerov, M., Meier, M. and Bahr, B. D.: A new index of glacier area change: a tool for glacier monitoring, J. Glaciol., 55, 710716, 2009.

Eypórsson, J.: Variations of glaciers 1931-1960, Jökull, 13, 31-33, 1963.

Flowers, G. E., Marshall, S. J., Björnsson, and Clarke, G. K. C.: Sensitivity of Vatnajökull ice cap hydrology and dynamics to climate warming over the next 2 centuries, J. Geophys. Res., 110, F02011, doi:10.1029/2004JF000200, 2005.

Flowers, G. E., Björnsson, H., Geirsdóttir, A., Miller, G. H., and Clarke, G. K. C.: Glacier fluctuation and inferred climatology of Langjökull ice cap through the Little Ice Age, Quaternary Sci. Rev., 26, 2337-2353, 2007.

Furbish, D. J. and Andrews, J. T.: The use of hypsometry to indicate long-term stability and response of valley glaciers to changes in mass transfer, J. Glaciol., 30, 199-211, 1984.

Gardner, A. S., Moholdt, G., Cogley, J. G., Wouters, B., Arendt, A. A., Wahr, J., Berthier, E., Hock, R., Pfeffer, W. T., Kaser, G., Ligtenberg, S. R. M., Bolch, T., Sharp, M. J., Hagen, J. O., van den Broeke, M. R., and Paul, F.: A Reconciled Estimate of Glacier Contributions to Sea Level Rise: 2003 to 2009, Science, 340, 852-857, doi:10.1126/science.1234532, 2013.

Glasser, N. F., Harrison, S., Jansson, K. N., Anderson, K., and Cowley, A.: Global sea-level contribution from the Patagonian Icefields since the Little Ice Age maximum, Nat. Geosci., 4, 303 307, doi:10.1038/Ngeo1122, 2011.

Guðmundsson, M. T.: Mass balance and precipitation on the summit of the plateau of Öræfajökull, SE-Iceland, Jökull, 48, 49-54, 2000.

Guðmundsson, S.: Reconstruction of late 19th century glacier extent of Kotárjökull and Breiðamerkurjökull in southeast Iceland and comparison with the current extent, MSc thesis, University of Iceland, Reykjavík, 2014.

Guðmundsson, S., Pálsson, F., Björnsson, H., and Haraldsson, H. H.: Comparison of energy balance and degreeday models of summer ablation on the Langjökull ice cap, SW-Iceland, Jökull, 59, 1-18, 2009.

Guðmundsson, S., Björnsson, H., Magnússon, E., Berthier, E., Pálsson, F., Guðmundsson, M. T., Högnadottir, T., and Dall, J.: Response of Eyjafjallajökull, Torfajökull and Tindfjallajökull ice caps in Iceland to regional warming, deduced by remote sensing, Polar Res., 30, doi:10.3402/Polar.V30i0.7282, 2011.

Guðmundsson, S., Hannesdóttir, H., and Björnsson, H.: Post-Little Ice Age volume loss of Kotárjökull glacier, southeast Iceland, derived from historical photography, Jökull, 62, 97-110, 2012.

Haeberli, W., Muller, P., Alean, P., and Bösch, H.: Glacier changes following the Little Ice Age - a survey of the international data basis and its perspectives, in: Glacier Fluctuations and Climatic Change, edited by: Oerlemans, J., Kluwer Academic Publishers, Utrecht, 1989.

Hannesdóttir, H., Björnsson, H., Pálsson, F., Aðalgeirsdóttir, G., and Guðmundsson, S.: Variations of southeast Vatnajökull ice cap (Iceland) 1650-1900 and reconstruction of the glacier surface geometry at the Little Ice Age maximum, Geograf. Ann., doi:10.1111/geoa.12064, online first, 2014.

Hawkins, M.: Equilibrium-line altitudes and paleoenvironment in the Merchants Bay area, Baffin island, N. W. T., Canada, J. Glaciol., 31, 205-213, 1985. 
Huss, M.: Extrapolating glacier mass balance to the mountain-range scale: the European Alps 1900-2100, The Cryosphere, 6, 713727, doi:10.5194/tc-6-713-2012, 2012.

Huss, M.: Density assumptions for converting geodetic glacier volume change to mass change, The Cryosphere, 7, 877-887, doi:10.5194/tc-7-877-2013, 2013.

Icelandic Meteorological Office and Institute of Earth Sciences, University of Iceland: DEMs of Icelandic glaciers (data set), The Icelandic Meteorological Office, Reykjavík, 2013.

James, T. D., Murray, T., Barrand, N. E., Sykes, H. J., Fox, A. J., and King, M. A.: Observations of enhanced thinning in the upper reaches of Svalbard glaciers, The Cryosphere, 6, 13691381, doi:10.5194/tc-6-1369-2012, 2012.

Jiskoot, H., Pedersen, A. K., Murray, T.: Multi-model photogrammetric analysis of the 1990s surge of Sortebræ, East Greenland, J. Glaciol., 47, 677-687, 2001.

Jiskoot, H., Curran, C. J., Tessler, D. L., and Shenton, L. R.: Changes in Clemenceau Icefield and Chaba Group glaciers, Canada, related to hypsometry, tributary detachment, lengthslope and area-aspect relations, Ann. Glaciol., 50, 133-143, 2009.

Jóhannesson, T., Raymond, C., and Waddington, E.: Time-Scale for Adjustment of Glaciers to Changes in Mass Balance, J. Glaciol., 35, 355-369, 1989.

Jóhannesson, T., Björnsson, H., Pálsson, F., Sigurðsson, O., and Thorsteinsson, T.: LiDAR mapping of the Snæfellsjökull ice cap, western Iceland, Jökull, 61, 19-32, 2011.

Jóhannesson, T., Björnsson, H., Magnússon, E., Guðmundsson, S., Pálsson, F., Sigurðsson, O., Thorsteinsson, T., and Berthier, E.: Ice-volume changes, bias estimation of mass-balance measurements and changes in subglacial lakes derived by lidar mapping of the surface of Icelandic glaciers, Ann. Glaciol., 54, 63-74, doi:10.3189/2013aog63a422, 2013.

Jones, P. D., Lister, D. H., Osborn, T. J., Harpham, C., Salmon, M., and Morice, C. P.: Hemispheric and largescale land surface air temperature variations: An extensive revision and an update to 2010, J. Geophys. Res., 35, L19502, doi:10.1029/2008GL034470, 2012.

Kääb, A. and Funk, M.: Modelling mass balance using photogrammetric and geophysical data: a pilot study at Griesgletscher, Swiss Alps, J. Glaciol., 45, 575-583, 1999.

Knoll, C., Kerschner, H., and Abermann, J.: Development of area, altitude and volume of South Tyrolean glaciers since the Little Ice Age maximum, Z. Gletscherk. Glazialgeol., 42, 19-36, 2008.

Korona, J., Berthier, E., Bernard, M., Remy, F., and Thouvenot, E.: SPIRI T. SPOT 5 stereoscopic survey of Polar Ice: Reference Images and Topographies during the fourth International Polar Year (2007-2009), Int. Soc. Photogram., 64, 204-212, doi:10.1016/j.isprsjprs.2008.10.005, 2009.

Kuhn, M., Markel, G., Kaser, G., Nickus, U., Obleitner, F., and Schneider, H.: Fluctuations of climate and mass balances: different responses of two adjacent glaciers, Z. Gletscherk. Glazialgeol., 21, 409-416, 1985.

Lüthi, M. P., Bauder, A., and Funk, M.: Volume change reconstruction of Swiss glaciers from length change data, J. Geophys. Res.-Earth, 115, F04022, doi:10.1029/2010jf001695, 2010.

Magnússon, E., Björnsson, H., and Pálsson, F.: Landslag í grennd Kvískerja í fortíð og framtíð: Niðurstöður ísjármælinga á Kvíár-
, Hrútár og Fjallsjökli (Radio echo sounding on Kvíárjökull, Hútárjökull and Fjallsjökull), Jökull, 57, 83-89, 2007.

Magnússon, E., Pálsson, F., Björnsson, H., and Guðmundsson, S.: Removing the ice cap of Öraefajokull central volcano, southeast Iceland: Mapping and interpretation of basal topography, ice volumes, subglacial troughs and implications for hazards assessments, Jökull, 62, 131-150, 2012.

Marshall, S. J.: Modelling glacier response to climate change, in: Glacier Science and Environmental Change, edited by: Knight, P. G., Blackwell Publishing, Malden, USA, 275-292, 2008.

Mathieu, R., Chinn, T., and Fitzharris, B.: Detecting the equilibrium-line altitudes of New Zealand glaciers using ASTER satellite images, New Zealand, J. Geol. Geophys., 52, 209-222, 2009.

Mernild, S. H., Pelto, M., Malmros, J. K., Yde, J. C., Knudsen, N. T., and Hanna, E.: Identification of snow ablation rate, ELA, AAR and net mass balance using transient snowline variations on two Arctic glaciers, J. Glaciol., 59, 649-659, doi:10.3189/2013jog12j221, 2013.

Oerlemans, J.: Estimating the reponse times of Vadret da Morteratsch, Vadret da Palu, Briksdalsbreen and Nigardsbreen from their length records, J. Glaciol., 53, 357-362, 2007.

Oerlemans, J., Anderson, B., Hubbard, A., Huybrechts, P., Johannesson, T., Knap, W. H., Schmeits, M., Stroeven, A. P., van de Wal, R. S. W., Wallinga, J., and Zuo, Z.: Modelling the response of glaciers to climate warming, Clim. Dynam., 14, 267274, 1998.

Osmaston, H. A.: Models for the estimation of firnlines of present and Pleistocene glaciers, in: Processes in physical and human geography: Bristol essays, edited by: Peel, R. F., Chisholm, M. D. I., and Haggart, P., Heinemann Educational Books Ltd, London, 218-245, 1975.

Östrem, G.: ERTS data in glaciology- an effort to monitor glacier mass balance from satellite imagery, J. Glaciol., 15, 403-415, 1975.

Pálsson, F., Guðmundsson, S., Björnsson, H., Berthier, E., Magnússon, E., Guðmundsson, S., and Haraldsson, H. H.: Mass and volume changes of Langjokull ice cap, Iceland, similar to $\sim 1890$ to 2009 , deduced from old maps, satellite images and in situ mass balance measurements, Jökull, 62, 81-96, 2012.

Paul, F., Kääb, A., Maisch, M., Kellenberger, T., and Haeberli, W.: Rapid disintegration of Alpine glaciers observed with satellite data, Geophys. Res. Lett., 31, L21402, doi:10.1029/2004g1020816, 2004.

Paul, F., Kääb, A., and Haeberli, W.: Recent glacier changes in the Alps observed by satellite: Consequences for future monitoring strategies, Global Planet. Change, 56, 111-122, doi:10.1016/j.gloplacha.2006.07.007, 2007.

Pelto, M. S.: Forecasting temperate alpine glacier survival from accumulation zone observations, The Cryosphere, 4, 67-75, doi:10.5194/tc-4-67-2010, 2010.

Rabatel, A., Machaca, A., Francou, B., and Jomelli, V.: Glacier recession on Cerro Charquini (16 degrees $S$ ), Bolivia, since the maximum of the Little Ice Age (17th century), J. Glaciol., 52, 110-118, doi:10.3189/172756506781828917, 2006.

Rabatel, A., Francou, B., Soruco, A., Gomez, J., Cáceres, B., Ceballos, J. L., Basantes, R., Vuille, M., Sicart, J.-E., Huggel, C., Scheel, M., Lejeune, Y., Arnaud, Y., Collet, M., Condom, 
T., Consoli, G., Favier, V., Jomelli, V., Galarraga, R., Ginot, P., Maisincho, L., Mendoza, J., Ménégoz, M., Ramirez, E., Ribstein, P., Suarez, W., Villacis, M., and Wagnon, P.: Current state of glaciers in the tropical Andes: a multi-century perspective on glacier evolution and climate change, The Cryosphere, 7, 81102, doi:10.5194/tc-7-81-2013, 2013.

Reinhardt, W. and Rentsch, H.: Determination of chnages in volume and elevation of glaciers using digital elevation models for the Veragtferner, Ötztal Alps, Austria, Ann. Glaciol., 8, 151-155, 1986.

Rivera, A., Benham, T., Casassa, G., Bamber, J., and Dowdeswell, J. A.: Ice elevation and areal changes of glaciers from the Northern Patagonia Icefield, Chile, Global Planet. Change, 59, 126-137, doi:10.1016/j.gloplacha.2006.11.037, 2007.

Schwitter, M. P. and Raymond, C. F.: Changes in the longitudinal profiles of glaciers during advance and retreat, J. Glaciol., 39, 582-590, 1993.

Shea, J. M., Menounos, B., Moore, R. D., and Tennant, C.: An approach to derive regional snow lines and glacier mass change from MODIS imagery, western North America, The Cryosphere, 7, 667-680, doi:10.5194/tc-7-667-2013, 2013.

Sigurðsson, F.: Vandamál við úrkomumælingar á Íslandi, in: Vatnið og landið, Vatnafræðiráđstefna, Október 1987, edited by: Sigbjarnarson, G., Orkustofnun, Reykjavík, 307, 101-110, 1990.

Sigurðsson, O.: Jöklabreytingar 1930-1970, 1970-1995, 19952011 og 2011-2012, Jökull, 63, 118-122, 2013.
Thórarinsson, S.: Oscillations of the Iceland glaciers in the last 250 years, Geogr. Ann. A, 25, 1-54, 1943.

Trussel, B. L., Motyka, R. J., Truffer, M., and Larsen, C. F.: Rapid thinning of lake-calving Yakutat Glacier and the collapse of the Yakutat Icefield, southeast Alaska, USA, J. Glaciol., 59, 149161, doi:10.3189/2013J0G12J081, 2013.

Vaughan, D. G., Comiso, J. C., Allison, I., Carrasco, J., Kaser, G., Kwok, R., Mote, P., Murray, T., Paul, F., Ren, J., Rignot, E., Solomina, O., Steffen, K., and Zhang, T.: Observations: Cryosphere, in: Climate Change 2013: The Physical Science Basis, Contribution of Working Group I to the Fifth Assessment Report of the Intergovernmental Panel on Climate Change, edited by: Stocker, T. F., Qin, D., Plattner, G.-K., Tignor, M., Allen, S. K., Boschung, J., Nauels, A., Xia, Y., Bex, V., and Midgley, P. M., Cambridge University Press, Cambridge, UK and New York, NY, USA, 317-382, 2013.

WGMS: Global Glacier Changes: Facts and Figures, Tech. rep., Zurich, Switzerland, 2008.

Wise, S.: Assessing the quality for hydrological applications of digital elevation models derived from contours, Hydrol. Process., 14, 1909-1929, doi:10.1002/10991085(20000815/30)14:11/12<1909::Aid-Hyp45>3.0.Co;2-6, 2000.

Zemp, M., Zumbuhl, H. J., Nussbaumer, S., Masiokas, M. H., Espizua, L. H., and Pitte, P.: Extending glacier monitoring into the Little Ice Age and beyond, PAGES News, 19, 67-69, 2011. 